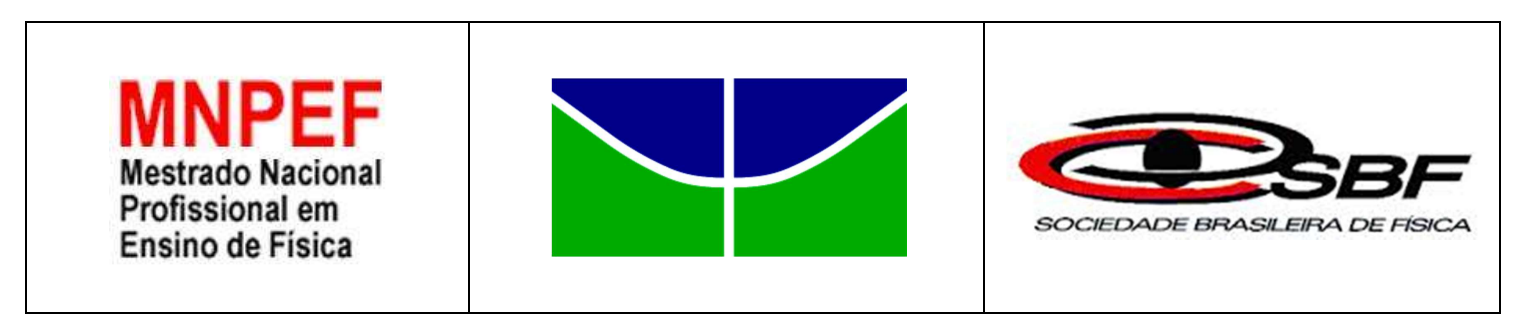

\title{
UTILIZAÇÃO DE VÍDEOS E SOFTWARES PARA O ENSINO DE MOVIMENTO HARMÔNICO SIMPLES, INTERFERÊNCIA EM ONDAS E EFEITO DOPPLER
}

JORGE LUÍS DE ARAÚJO COELHO

Dissertação de Mestrado apresentada ao Programa de Pós-Graduação da Universidade de Brasília no Curso de Mestrado Nacional Profissional de Ensino de Física (MNPEF), como parte dos requisitos necessários à obtenção do título de Mestre em Ensino de Física.

Orientador:

Prof. Dr. Fábio Ferreira Monteiro

Brasília

Dezembro de 2016 


\title{
UTILIZAÇÃO DE VÍDEOS E SOFTWARES PARA O ENSINO DE MOVIMENTO HARMÔNICO SIMPLES, INTERFERÊNCIA EM ONDAS E EFEITO DOPPLER
}

\author{
JORGE LUIS DE ARAÚJO COELHO
}

Orientador:

Prof. Dr. Fabio Monteiro Ferreira

Dissertação de Mestrado submetida ao Programa de Pós-Graduação da Universidade de Brasília no Curso de Mestrado Nacional Profissional de Ensino de Física (MNPEF), como parte dos requisitos necessários à obtenção do título de Mestre em Ensino de Física

Aprovada por:

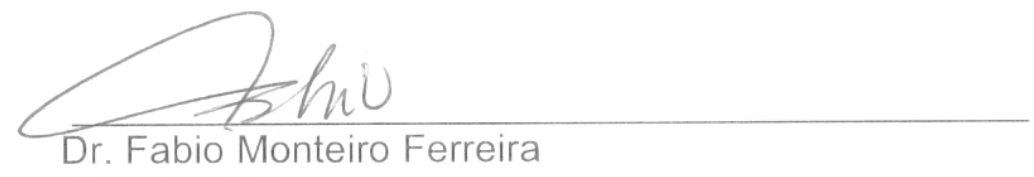
(Presidente)

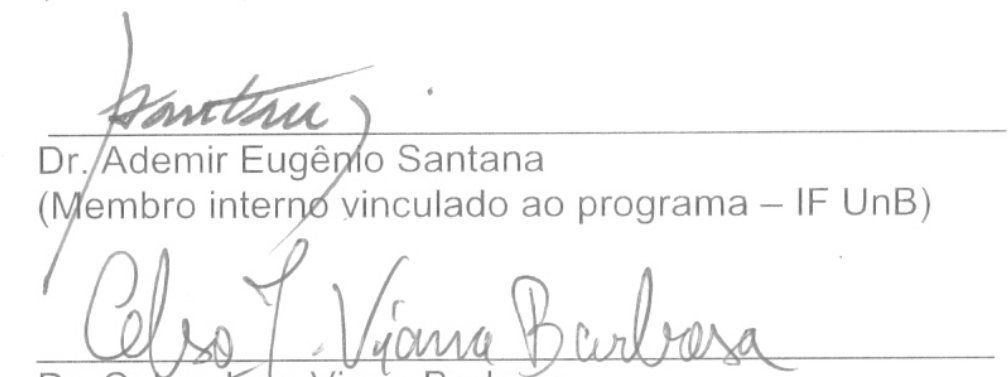

Dr. Celso Jose Viana Barbosa

(Membro externo não vinculado ao programa - UFSE)

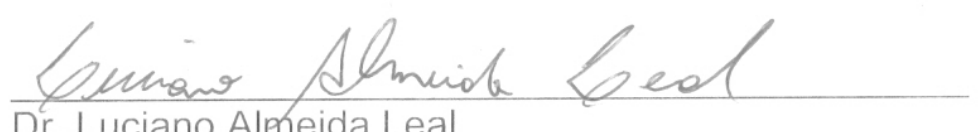

Dr. Luciano Alpreida Leal

(Membro externo não vinculado ao programa - CMB)

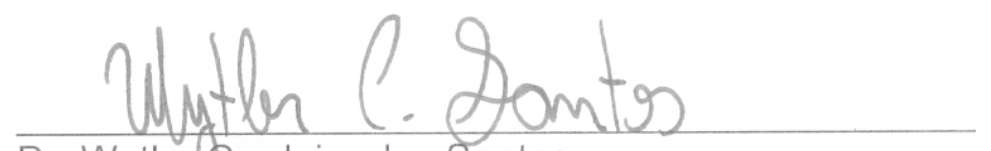

Dr. Wytler Cordeiro dos Santos

(Membro interno vinculado ao programa - IF UnB)

Brasília

Dezembro de 2016 
Coelho, Jorge Luís de Araújo

Utilização de vídeos e softwares para o o ensino de movimento harmônico simples, interferência em ondas e Efeito Doppler / Jorge Luís de Araújo Coelho - Brasília: UnB / IF, 2016.

viii, 65 f.: il.; $30 \mathrm{~cm}$.

Orientador: Fabio Ferreira Monteiro

Dissertação (mestrado) - UnB / Instituto de Física / Mestrado

Profissionalizante em Ensino de Física, 2016.

Referências Bibliográficas: f. 63-64 fl.

1. Ensino de Física. 2. Vídeos. 3. softwares.

I. Ferreira, Fabio Monteiro. II. Universidade de Brasília, Instituto de

Física, Mestrado Nacional Profissionalizante em Ensino de Física. III.

Utilização de vídeos e softwares para o ensino de movimento harmônico simples, interferência em ondas e Efeito Doppler. 


\section{Agradecimentos}

- Ao meu orientador Prof. Fábio Ferreira Monteiro pela confiança, paciência e críticas realizadas durante a elaboração dessa pesquisa.

- À minha esposa Maria Aparecida Guedes Braz pela paciência, conselhos e carinho cedidos a mim nestes 9 anos.

- Aos meus filhos Melissa Guedes de Araújo Coelho e João Augusto Guedes de Araújo Coelho pelo amor cedido de forma incondicional e o sorriso de todas as manhãs.

- Aos meus pais, Francisco e Sônia pelo amor e conforto que nunca me deixaram faltar; irmãs Barbara e Ciomara e irmão João por serem o que são.

- Ao amigo Caio Polito pela colaboração, paciência, compartilhamento de ideias não só sobre Ensino ou Física, mas pela filosofia e a quase-antropologia.

- Aos amigos: Frank Sales, Leonardo Quadros pelos momentos divertidos e pelas discussões sobre física, política e cotidiano; Fabhio, Aline, Hartmann, Córes e Carvalho pelas gozações e seriedades; Cel Bandeira, Cel Nunes, Cel Neves Penteado e Maj Márcia por compreenderem minha ausência na seção e sempre me apoiar.

- Aos Professores do Mestrado Nacional Profissional em Ensino de Física pelas lições dadas de forma direta ou indiretamente durante toda a minha formação.

- Aos colegas Jefferson, Laelton, Dmuthie, João entre outros que felizmente tive a oportunidade de ser contemporâneo no programa de pós-graduação.

- À CAPES e ao Colégio Militar de Brasília pelo suporte financeiro. 


\section{Resumo}

O processo de ensino-aprendizagem em Física é comumente realizado por meio do algoritmo tradicional em várias instituições escolares do Brasil. Tal procedimento se baseia em uma exposição da teoria pelo professor e resoluções de exercícios. Esse paradigma já está obsoleto e existem variadas pesquisas indicando outras metodologias capazes de fornecer resultados mais efetivos para o desenvolvimento cognitivo do discente. A valorização da observação dos fenômenos e sua caracterização precisa ocupar lugar de destaque na compreensão da Física. Nosso trabalho consistiu em elaborar sequências didáticas pautadas nas teorias de aprendizagens de Ausubel e Vygostky, fornecendo uma metodologia diferenciada das práticas vigentes na escola tradicional. Assim, resolvemos construir sequências didáticas próximas de Unidade de Ensino Potencialmente Significativa cuja autoria se deve ao Professor M. A. Moreira que valoriza a aprendizagem significativa. Procedemos à elaboração de três sequências didáticas que abordam os assuntos: Movimento Harmônico Simples, Interferência em Ondas e Efeito Doppler. São constituídas por atividades que utilizam vídeos capazes de expor claramente os fenômenos Físicos, modelagem em computador que reproduzem esses fenômenos e operação de laboratórios virtuais para posterior análise do fenômeno. Tais sequências didáticas foram aplicadas e experienciadas por alunos do Segundo Ano do Ensino Médio do Colégio Militar de Brasília. 


\section{Abstract}

The process of teaching and learning in physics is commonly done through traditional algorithm in various educational institutions in Brazil. This procedure is based on an exposition of the theory by the teacher and resolutions of exercices. This paradigm is obsolete and there are various researchers indicating other methodologies that able to provide more effective results for the cognitive development of students. Valuing observation of phenomena and their precise characterization holds prominent place in the understanding of physics. Our job was to prepare Didactic sequences guided by the theories of learning of Ausubel and Vygotsky, providing a different methodology of existing practices in traditional school. So resolve to build didactic sequences near Teaching Unit Potentially Significant whose authorship is due to Professor M. A. Moreira values the meaningful learning. We proceeded to elaboration of three sequences teaching that address the issues: Simple Harmonic Motion, Interference Waves and Doppler effect. They consist of activities that use video capable clearly expose the Physical phenomena, computer modeling that play these phenomena and operation of virtual laboratories for further analysis phenomenon. Such didactic sequences were used and experienced by students According High School Year of the Military College of Brasilia. 


\section{Índice}

$\begin{array}{ll}\text { Lista de Figuras } & 1\end{array}$

1 Introdução 3

2 Teorias de Aprendizagem e Ensino no Sistema Colégio Militar $\quad 7$

2.1 Elementos da Teoria de Ausubel . . . . . . . . . . . . . . . . . 7

2.2 Aspectos gerais do Sócio-Interacionismo de Lev-Vygotsky . . . . . . . 12

2.3 Ensino por Habilidades e Competências no Sistema Colégio Militar . 15

3 Sequências Didáticas para abordagem do Movimento Harmônico Simples, Interferência e Efeito Doppler 20

3.1 Síntese de uma Unidade de Ensino Potencialmente Significativa . . . 20

3.2 O movimento hamônico simples por meio de uma quase-UEPS . . . . 23

3.3 O efeito de interferência em ondas utilizando elementos de UEPS . . 27

3.4 Abordagem do efeito Doppler por uma UEPS modificada . . . . . . . 32

4 Relato da experiência didática e análises $\quad 36$

4.1 O ambiente escolar e a aplicação das sequências didáticas . . . . . . . 36

4.2 Percepção discente das aplicações das sequências didáticas . . . . . . 51

5 Conclusão $\quad 55$

A Questões apresentadas as turmas nas sequências didáticas a fim de diagnóstico 
A.1 Questões sobre a máquina a vapor e o Movimento Harmônico Simples: . . . . . . . . . . . . . . 57

A.2 Questões sobre a propagação das ondas na superfície do lago e interferência: . . . . . . . . . . . . . 58

A.3 Questões sobre caracterísicas da frequência e Efeito Doppler: . 58

B Roteiro de Laboratório Didático $\quad 60$

C Questionário de avaliação das sequências didáticas $\quad 62$

$\begin{array}{ll}\text { Referências Bibliográficas } & 65\end{array}$ 


\section{Lista de Figuras}

3.1 Matriz Teórica de uma UEPS . . . . . . . . . . . . . . . . . . . 22

3.2 Máquina a Vapor de Vidro . . . . . . . . . . . . . . . . . . . . . 24

3.3 Abertura do software Modellus X . . . . . . . . . . . . . . . . . 24

3.4 Tela de configuração para simulação do movimento circular . . . . . . 25

3.5 Movimento circular e sua projeção . . . . . . . . . . . . . . 25

3.6 Software comercial Newton . . . . . . . . . . . . . . . . 26

3.7 Sistema massa-mola, pêndulo e corpo girante no software Newton . . 26

3.8 Propagação de ondas na superfície de um lago. . . . . . . . . . . . 28

3.9 Interferência em ondas na superfície de um lago. . . . . . . . . . . 28

3.10 Tela inicial do software Ondas. . . . . . . . . . . . . . . . . . . . 29

3.11 Padrão de interferência em superfícies. . . . . . . . . . . . . . . 30

3.12 Propagação da onda em superfície. . . . . . . . . . . . . . . . . 31

3.13 Interferência na propagação de onda em superfície. . . . . . . . . . . 31

3.14 Interferência na propagação de onda sonora. . . . . . . . . . . . . . 32

3.15 Variação de frequência sonora. . . . . . . . . . . . . . . . . . . 33

3.16 Modo de vibração da onda em função da frequência. . . . . . . . . . . 33

3.17 Apresentação do Efeito Doppler pelo Mago da Física. . . . . . . . . . 34

3.18 Site de divulgação de simulações no software Modellus. . . . . . . . . 34

3.19 Configuração das frentes de onda no Efeito Doppler. . . . . . . . . . . 35

4.1 Calendário do Colégio Militar de Brasília. . . . . . . . . . . . 37

4.2 Identificação dos tipos de movimentos das partes da máquina a vapor. 38 
4.3 Percepções da relação entre o movimento das partes da máquina a vapor. 39

4.4 Respostas identificando as funções matemáticas. . . . . . . . . . . . . 40

4.5 Respostas sobre a identificação das ondas na superfície do lago. . . . 43

4.6 Respostas reconhecendo os elementos de ondas. . . . . . . . . . . . . 44

4.7 Respostas identificando o fenômeno de superposição. . . . . . . . . . . 45

4.8 Respostas caracterizando frequência. . . . . . . . . . . . . . . . . . . 47

4.9 Respostas sobre frequência. . . . . . . . . . . . . . . . 48

4.10 Respostas sobre a influência do estado de movimento da fonte na frequência. . . . . . . . . . . . . . . . . . . . . . . 49

4.11 Perguntas sobre o objeto do conhecimento - Sequência Didática . . . 52

4.12 Perguntas sobre o recurso audiovisual . . . . . . . . . . . . . . . . 53

4.13 Resultado da autoavaliação . . . . . . . . . . . . . . 54 


\section{Introdução}

A Física é um componente curricular do ensino médio há mais de 150 anos, sua introdução nesse nível de ensino é marcada com a fundação do Colégio Pedro II no Rio de Janeiro em 1837 [1]. Ao longo desses anos a sociedade apresentou mudanças significativas, as relações interpessoais foram intensificadas e as distâncias físicas encurtadas pela tecnologia, o conceito de família se modificou e hoje os elementos que constituem essa instituição apresentam funções bem diferentes das de 30 anos atrás, a exemplo, a esposa/mãe exerce atividades laborais fora do âmbito doméstico deslocando a responsabilidade educacional também para o marido/pai. Verifica-se também que os extratos sociais não se mostram mais herméticos e a instituição escola foi democratizada por meio da ampliação do sistema educacional. Entretanto, algumas instâncias apresentam padrões incensíveis ao curso do tempo e as mudanças que esse traz consigo, a classe política ainda é movida por interesses partidários estanques aos sociais, o capital continua ditando o ritmo das mudanças em detrimento de um contexto holístico e a prática docente, em larga escala, se manteve tradicional no decurso dos anos [2,3].

A constatação de que o método de ensino-aprendizagem tradicional necessita de reformulação a fim de produzir melhor resultado é uma questão bem estabelecida por pesquisadores de ensino-aprendizagem [4]. O algoritmo básico utilizado no processo de ensino-aprendizagem é fundamentado na preparação para resolução de exercícios cuja intenção é obter um bom resultado em processos de avaliação em massa como vestibulares. Tal prática é corroborada pelo perfil da grande maioria dos livros didáticos disponíveis para docentes e discentes cuja característica comum e notória é a carência de uma abordagem fenomenológica e conceitual em prol de um destaque 
considerável a resolução de exercícios de vestibular. Esse modelo acaba por reforçar a memorização e apela para soluções estritamente algébricas em detrimento da intuição e observação crítica necessária para compreensão dos fenômenos físicos. Infelizmente o cenário ora delineado ocorre em uma gama considerável de estabelecimentos de ensino por todo o país e isso resulta em uma descaracterização na função do ensino médio definida nas Leis de Diretrizes e Bases da Educação - LDB e nos Parâmetros Curriculares Nacionais do Ensino Médio - PCNEM [5, 6, 7].

Na tentativa de fornecer uma alternativa à realidade da prática docente destacada no parágrafo anterior existe um conjunto considerável de propostas para o processo de ensino-aprendizagem se modernizar. Tais metodologias são capazes de subsidiar o professor com uma orientação clara e precisa fornecendo uma estrutura bem definida para sua aplicação em sala de aula. Entre essas opções é possível destacar duas: a prática do Peer Instruction e a elaboração de Unidades de Ensino Potencialmente Significativas $[8,9]$.

O Peer Instruction desenvolvido por E. Mazur consiste, em linhas gerais, de uma metodologia denominada Ativa, onde os discentes se responsabilizam pelo estudo prévio dos temas propostos, em aula participam de um debate sobre o assunto e por fim realizam atividades que se desenvolvem de forma colaborativa. O cerne do método está na utilização do estudante que aprendeu o conceito e consegue fazer atividades associativas e generalizantes ser incluído rapidamente no processo ensino. Esse aluno ainda se recorda das dificuldades que enfrentou para atingir a compreensão. Assim, pode colaborar ativamente na superação das dificuldades do colega aprendiz, pois reconhece o núcleo da dificulade de maneira mais rápida que o professor. Essa metodologia de ensino-aprendizagem apresenta uma aproximação a Teoria do Sócio-Interacionismo de Vygotsky [10, 11].

A formulação de uma Unidade de Ensino Potencialmente Significativa (UEPS) pode ser sintetizada como uma metodologia elaborada por M. A. Moreira que aproveita aspectos da Teoria de Aprendizagem de Ausubel, teoria interacionista social de Lev Vygotsky, teoria dos campos conceituais de Gérard Vergnaud e a teoria dos modelos mentais de Philip Johnson-Laird [12]. Por congregar uma miríade considerável de teorias de aprendizagem consegue estabelecer um processo de ensino-aprendizagem robusto e bem definido, onde cada uma das teorias citadas fornece o seu melhor em pontos específicos do processo de ensino aprendizagem. De forma geral uma UEPS pode ser elaborada destacando quatro etapas principais: (i) o diagnóstico, a fim de se verificar a existência de subsunçores utilizáveis para ação de um organizador prévio 
definido pelo professor; (ii) a escolha de organizadores prévios, conjunto de instrumentos selecionados de acordo com o diagnóstico e compatível com nível de cognição do discente tornando-se apropriadamente inteligível e assim pode evitar uma frustração, o que prejudicaria a pré-disposição do discente em compreender; (iii) composição de uma aula dialogada e avaliação formativa, a fim de conduzir e estabelecer pontos de verificação da mudança conceitual significativa; e (iv) avaliações somativas finais e avalição da UEPS, verificando os níveis atingidos pelos discentes e a efetividade da UEPS. Nessa estrutura, os itens (ii) e (iii) podem ser entendidos como a ação de aula propriamente dita.

Ambas metodologias são propostas que deslocam o trabalho exclusivamente expositivo do docente para uma participação ativa do discente, a ênfase no conteudismo e repetição exaustiva com intuito de preparação exclusiva para exames é substituída por uma prática colaborativa do discente. A "pedagogia da interação", ou seja, um processo de ensino-aprendizagem onde a construção do conhecimento ocorre a medida que o aluno se torna um agente ativo, sujeito da ação, na busca de uma compreensão que ocorre por meio da exposição de situações problemas. Assim, quando se fala em metodologia ativa, compreende-se uma concepção educativa que estimula processos de ação-reflexão-ação, de forma que o aluno assume uma posição de protagonista no seu aprendizado. Portanto, pode vivenciar situações práticas abordadas de forma instigante, que lhe favoreçam à pesquisa, à descoberta de processos, a construção de explicações, soluções aplicáveis e passíveis de generalizações e imersão em variadas situações reais ou conjecturadas [13].

A partir dessas observações elaboramos uma questão que orientou a nosso trabalho:

É possível obter uma aprendizagem significativa sobre conceitos de Movimento Harmônico Simples, Interferência na Ondulatória e Efeito Doppler, sem transformar a aula em um mero instrumento preparatório para vestibulares?

O objetivo geral deste trabalho pode ser definido como

Produzir Sequências Didáticas que se aproximam de Unidades de Ensino Potencialmente Significativas (UEPS) abordando o Movimento Harmônico Simples, Ondulatória e Efeito Doppler as quais possam ser facilmente obtidas e aplicadas por outros docentes. 
Os objetivos específicos podem ser delineados por:

- realizar uma seleção na internet de vídeos públicos que abordem os assuntos de maneira apropriada para se tornar um organizador prévio;

- identificar programas de computador que auxiliem o desenvolvimento do assunto;

- construir uma sequência didática e utilizar no ensino médio;

- aplicar e analisar questionários a fim de encontrar indícios que a sequência didática proporcionou aprendizagem significativa.

A dissertação apresenta quatro capítulos os quais descrevem as etapas seguidas para elaborar o produto educacional.

O capítulo 2 apresenta uma revisão bibliográfica a respeito da Teoria de Ausubel e do Sócio-Interacionisno de Lev-Vygotsky em virtude de tais autores formarem a base teórica da proposta da sequência didática elaborada. Além disso, foi realizada uma síntese da filosofia do processo de Ensino-Aprendizagem adotada no Sistema Colégio Militar do Brasil.

No capítulo 3 expomos a metodologia por meio de conceitos gerais de Unidades de Ensino Potencialmente Significativas que serviram de referência para construção das Sequências Didáticas. Também realizamos nesse capítulo a exposição das Sequências Didáticas elaboradas para o Movimento Harmônico Simples, Fenômeno de Interferência na Ondulatória e Efeito Doppler.

A análise dos resultados é feita de maneira qualitativa e está exposta no capítulo 4 apresentando as considerações sobre a condução das Sequências Didáticas em sala de aula e a percepção dos discentes sobre o produto aplicado.

Por fim, no capítulo 5, apresentamos nossas conclusões e perspectivas de trabalhos futuros. 
Capítulo 2

\section{Teorias de Aprendizagem e Ensino no Sistema Colégio Militar}

Será apresentado neste capítulo, uma breve discussão a respeito de alguns conceitos e propriedades relacionadas a Teoria de Ausubel e ao Sócio-Interacionismo de Lev Vygotsky. Além disso realizaremos uma síntese do processo de ensino-aprendizagem por habilidades e competências adotado no Sistema Colégio Militar de Ensino. A ideia é expor os principais aspectos dessas teorias de aprendizagem as quais formam a base teórica do produto educacional constituído por sequências didáticas que se ajustem bem as características do sistema de ensino do colégio militar e assim possam ser apropriadamente aplicadas.

\subsection{Elementos da Teoria de Ausubel}

Na tentativa de estruturar o processo de ensino-aprendizagem Benjamin S. Bloom e colaboradores organizaram os conhecidos domínios da aprendizagem: cognitivo, afetivo e psicomotor [14]. Nosso interesse se relaciona ao domínio cognitivo o qual se caracteriza pelas questões de armazenamento organizado do conhecimento e sua mobilização em ações.

Um dos principais representantes do cognitivismo como teoria de Aprendizagem é a proposta de Ausubel [15], a qual trata a aprendizagem de forma descritiva e sistêmica. O foco dessa teoria está voltado para os ambientes de aprendizagem escolares e assim propõe uma explicação teórica do processo de aprendizagem fundamentado sobretudo em aspectos cognitivistas, embora reconheça a importância do domínio 
afetivo. Assim, como outros teóricos do cognitivismo, relaciona a aprendizagem com a organização, integração e operacionalização do material de conhecimento na estrutura cognitiva. Desta forma, a estrutura cognitiva é entendida como o conteúdo total de ideias de um indivíduo, sua organização e mobilização.

A teoria de Ausubel atribui função especial no processo de ensino-aprendizagem escolar a grande influencia do que o aluno já sabe, ou seja, suas concepções prévias. Novas ideias e informações podem ser aprendidas e retidas na medida em que conceitos relevantes e inclusivos já estejam adequadamente claros e disponíveis na estrutura cognitiva do indivíduo e assim possam funcionar como ponto de ancoragem às novas ideias e conceitos. Entretanto, o advento da cognição não se limita à influência dos conceitos já aprendidos sobre componentes da nova aprendizagem, mas se estende também pelas modificações relevantes nos atributos da estrutura cognitiva dada pela influência do novo material. Desta forma, existe um processo de interação por meio do qual conceitos mais relevantes e inclusivos interagem com o novo material, funcionando como ancoradouro, isto é, abrangendo e integrando este material e, ao mesmo tempo, modificando-se em função dessa ancoragem.

\section{Aprendizagem significativa, subsunçores e organizadores prévios}

Na teoria de Ausubel a aprendizagem tem significado especial, trata-se de um processo onde uma nova informação relaciona-se com um aspecto específico e relevante da estrutura de conhecimento do indivíduo, ou seja, ocorre a interação da nova informação com uma estrutura de conhecimento já estabelecida, a qual Ausubel define como conceito subsunçor; ou apenas subsunçor. A aprendizagem significativa ocorre quando a nova informação ancora-se em conceitos ou proposições relevantes, preexistentes na estrutura cognitiva do aprendiz. Ausubel entende o armazenamento de informações no cérebro humano como uma organização hierárquica conceitual, na qual elementos mais específicos de conhecimento são conectados e assimilados a conceitos mais gerais, mais inclusivos. Todavia, este processo não exclui a preexistência de subsunçores abrangentes e bem desenvolvidos, ou mesmo limitados e pouco desenvolvidos, pois, dependendo da frequência com que ocorreram outras aprendizagens significativas a estrutura cognitiva do sujeito pode ser caracterizada de forma singular.

Ausubel define outra aprendizagem denominada mecânica (ou automática) como sendo a aprendizagem de novas informações com pouca ou nenhuma interação com 
conceitos relevantes existentes na estrutura cognitiva. Assim, a nova informação é armazenada de maneira arbitrária. Uma observação importante sobre a aprendizagem significativa e a aprendizagem mecânica trata-se de não existir uma dicotomia/antagônia e sim um processo contínuo e reflexivo, ou seja, é possível dar significação a algo que foi automatizado. De fato, a aprendizagem mecânica é necessária quando um indivíduo adquire informações em uma área de conhecimento completamente nova para ele e passa a iniciar um processo de ensino-aprendizagem naquele campo.

Existem situações onde o contato do indivíduo com o objeto a ser abordado na aprendizagem não ocorreu em nenhuma instância formal, logo não é garantida a presença prévia de conceitos subsunçores. Todavia, não existe a tábula rasa, ou seja, a experienciação do habitat pelo indivíduo pode produzir um conjunto de subsunçores mínimos ainda que pouco elaborados. Logo, à medida que a aprendizagem começa a ser significativa, esses subsunçores tornan-se cada vez mais robustos e capazes de ancorar novas informações. Ao atingir a idade escolar, a maioria das crianças já possui um conjunto adequado de conceitos que permite a ocorrência da aprendizagem significativa. A partir daí, mesmo que ainda aconteça a formação de conceitos, a maioria é adquirida mediante assimilação, diferenciação progressiva e reconciliação integrativa dos conceitos, tais processos serão abordados posteriormente. A utilização de organizadores prévios serve para estabelecer âncoras para nova aprendizagem e assim promover o desenvolvimento de conceitos subsunçores que vão fornecer subsídios a aprendizagem subsequente. O uso de organizadores prévios é uma estratégia proposta por Ausubel para, intencionalmente, operar sobre a estrutura cognitiva e assim possibilitar a aprendizagem significativa. Organizadores prévios são materiais introdutórios apresentados antes do assunto a ser aprendido em si. A função fundamental do organizador prévio é servir de ponte entre o que o estudante já sabe e o que ele deve saber, a fim de que o assunto possa ser aprendido de forma significativa, ou seja, são "pontes cognitivas".

\section{Condições, evidências e tipos de aprendizagem significativa}

O processo de aprendizagem significativa se caracteriza pela relação substantiva e não arbitrária de novos conceitos aos que o estudante já conhece. Uma das condições para a ocorrência da aprendizagem significativa é a utilização de material relacionável à estrutura cognitiva do aluno de forma orientada e não literal. Esses materiais 
são denominados potencialmente significativos. Desta forma, a transformação do material potencial em efetivo ocorre a medida que o estudante tenha disponível em sua estrutura cognitiva os subsunçores adequados a realização da aprendizagem. Além disso, o estudante deve estar predisposto a relacionar de maneira substantiva e não arbitrária o novo material, potencialmente significativo, à sua estrutura cognitiva. Portanto, essa condição implica que, independentemente do potencial significativo do material a ser aprendido, se a intenção do aprendiz for simplesmente memorizá-lo, arbitrária e literalmente, tanto o processo de aprendizagem como seu produto serão mecânicos.

A compreensão de um conceito ou proposição manifesta a posse de significados claros, precisos, diferenciados e transferíveis. Ao se avaliar essa compreensão, pedindo ao aluno que explicite quais os atributos essenciais de um conceito ou os elementos essenciais de uma proposição, corre-se o risco de obter apenas respostas memorizadas. Assim, é necessário evitar "problemas típicos" e utilizar questões e problemas de uma maneira inédita e não familiar, os quais requerem transformação do conhecimento adquirido e assim poderão evidenciar aprendizagem significativa.

A teoria de Ausubel expõe três tipos de aprendizagem significativa: representacional, de conceitos e proposicional. A aprendizagem representacional é um nível mais simples de aprendizagem significativa, do qual os demais dependem. Envolve a identificação, em significação, de símbolos com seus referentes, ou mesmo a atribuição de significados a símbolos específicos. Os símbolos passam a significar, para o indivíduo, aquilo que seus referentes significam. A aprendizagem de conceitos pode ser entendida como uma aprendizagem representacional diferenciada, pois os conceitos são também representados por símbolos particulares; porém, são genéricos ou categóricos, representam abstrações dos atributos essenciais dos referentes, isto é, representam regularidades em eventos ou objetos. Na aprendizagem proposicional, contrariamente à aprendizagem representacional, a tarefa não é aprender significativamente o que os símbolos isolados ou combinados representam, e sim, aprender o significado de ideias em forma de proposição.

\section{Subordinação, superordenação, combinação, diferenciação progressiva e reconciliação integrativa}

É possível notar características de relações no processo de aprendizado significativo descrito por Ausbel. Percebe-se que o fato da nova informação adquirir signi- 
ficado por meio da interação com subsunçores, reflete uma relação de subordinação do novo material em relação à estrutura cognitiva preexistente. De outra forma, a aprendizagem superordenada ocorre quando um conceito ou proposição potencialmente significativo, mais amplo e inclusivo que ideias ou conceitos já estabelecidos na estrutura cognitiva seja adquirido por meio dessas estruturas mais simples e passa a assimilá-las. A aprendizagem combinatória é caracterizada pela aprendizagem de proposições, em menor escala, de conceitos que não guardam uma relação de subordinação ou superordenação com proposições ou conceitos específicos, e sim, com conteúdo amplo.

A diferenciação progressiva de um conceito subsunçor ocorre pelo processo de aprendizado por subordinação, isto é, por um processo de interação e ancoragem. $\mathrm{Na}$ aprendizagem superordenada (ou na combinatória), ideias estabelecidas na estrutura cognitiva podem receber uma nova significação no curso de novas aprendizagens. Desta forma, a medida que novas informações são adquiridas os elementos existentes na estrutura cognitiva podem reorganizar-se e ser reinterpretados ocorrendo a reconciliação integrativa. A teoria de Ausubel destaca que a diferenciação progressiva pode ser evidenciada por meio de um princípio programático da matéria de ensino, segundo o qual as ideias, conceitos, proposições mais gerais e inclusivos do conteúdo devem ser apresentados no início da sequencia didática e, progressivamente, diferenciados em termos de detalhes e especificidades.

O processo instrucional na Teoria de Ausubel destaca a importância do estado da estrutura cognitiva do aprendiz no momento da aprendizagem. Traz consigo, tanto em termos de conteúdo como de organização, características que podem ser influenciadas por duas maneiras: 1) substantivamente, pela apresentação, ao aprendiz, de conceitos e princípios unificadores e inclusivos, com maior poder explanatório e propriedades integradoras; 2) programaticamente, pelo emprego de métodos adequados de apresentação do conteúdo e utilização de princípios programáticos apropriados na organização sequencial da matéria de ensino.

A síntese dos conceitos e observações da Teoria de Ausubel ora apresentada podem orientar adequadamente a base de sequências didáticas propostas como produto de ensino em Física. São capazes de fornecer estruturas onde o processo pode se apoiar e promover uma aprendizagem significativa. 


\subsection{Aspectos gerais do Sócio-Interacionismo de Lev- Vygotsky}

Apesar da Teoria de Ausubel não ser explícita em relação as interações entre indivíduos no processo de ensino-aprendizagem é evidente que o ambiente escolar manifesta interações que mediam o processo. Desta forma, observamos algumas abordagens da teoria sócio-interacionista de Vygotsky a qual parte da premissa que o desenvolvimento educacional não pode ser entendido sem referência ao contexto social e cultural no qual ele ocorre. Nessa teoria a definição dos processos mentais superiores como pensamento, linguagem e comportamento é realizada salientando que esses têm origem em processos sociais; o desenvolvimento cognitivo do ser humano não pode ser entendido sem referência ao meio social. Também é destacado que as relações sociais serão transformadas em funções psicológicas por meio da mediação, ou atividade mediada indireta, caracterizando que pela mediação se faz a internalização. Desta forma, a conversão de relações sociais em funções mentais superiores não é direta, é intermediada por elementos que inclui instrumentos e signos. Os instrumentos são identificados como qualquer mecanismo que pode ser usado para fazer alguma coisa; um signo é algo que impressiona a percepção a fim de ser reportado a algum outro elemento. Existem três tipos de signos: 1) indicadores, são aqueles que têm uma relação de causa e efeito com aquilo que significam; 2) icônicos, são imagens ou desenhos daquilo que significam; 3) simbólicos, são os que têm uma relação abstrata com o que significam. O desenvolvimento cognitivo se faz por meio da apropriação de instrumentos e signos os quais são construções elaboradas por interação social. Assim, os processos mentais superiores se transformam a medida que ocorre a interiorização continua e acumulativa de signos o que pode ampliar de forma ilimitada a quantidade de ações realizáveis por tais processos mentais.

O processo de internalização dos signos se faz pela captação de significados já compartilhados socialmente. Desta forma, a interação social é essencial, pois a compreensão de significados se faz por estruturas que se estabelecem dado um processo de intercâmbios e aprimoramentos fornecendo assim à interação social o status de unidade de análise. Essa conceituação não é evidente na Teoria de Ausubel a qual focaliza o indivíduo como unidade de análise. As pluralidades de grupos sociais afetam diretamente a aquisição de conhecimento em virtude de proporcionar diferenças nas concepções dos signos. Assim, pode-se compreender diferentes níveis de interiorização nos indivíduos que mantém relações sociais distintas. Além disso, o próprio contato 
social consigo mesmo é estabelecido de acordo com a disponibilidade de signos ao indivíduo e pelo qual mobiliza sua adapção de maneira singular num grupo social.

O processo de ensino-aprendizagem no socio-interacionismo de Vygotsky é descrito pela ação de instrução em estruturas conhecidas como zonas. Essencialmente essas zonas estabelecem diferenças a respeito do arcabouço de conhecimento disponível, em contraste com o conhecimento potencial. A região intermediária, conhecida como Zona de Desenvolvimento Proximal, deve ser a região onde as interações sociais se apliquem a fim de promover a interiorização de novos elementos que venham produzir o desenvolvimento cognitivo, ou seja, a aprendizagem. Os instrumentos de aprendizagem são orientados externamente; constituem um mecanismo pelo qual a atividade humana é dirigida para o controle e domínio do meio de forma que estabeleça relações sociais variadas e permita a mobilização de signos complexos.

\section{Aspectos gerais de formação de conceitos, aprendizagem e ensino}

O processo de formação de conceitos foi estudado experimentalmente por Vygostsky e colaboradores. Eles perceberam que em diferentes fases da vida a aprendizagem se faz por mecanismos onde os signos são captados de forma distinta. Num primeiro momento, ocorre predominantemente a agregação desorganizada, não se tem um entendimento claro do signo e sim uma ideia difusa, a associação de objetos não satisfaz critérios evidentes de relação e são trabalhados predominantemente em função do campo visual e sua localização espacial. Em seguida, o pensamento passa a se organizar por complexos: nesta segunda fase, os objetos são agrupados não só por causa das impressões subjetivas, mas também em razão de relações que de fato existem entre esses objetos. Há nesta fase uma sucessão de estágios em função das relações construídas entre os objetos: associativa, ligada a atributos comuns; de coleções, relacionadas a atributos complementares; em cadeia, em que as associações são feitas a partir de sequências de atributos. Por fim, organizam-se os conceitos potenciais que resultam de uma espécie de abstração primitiva e usualmente não sucedem o estágio dos pseudoconceitos, pois geralmente já está presente em certo grau nas fases iniciais do desenvolvimento cognitivo.

Na perspectiva de Vygotsky o bom ensino ocorre a medida que se aponta para o desenvolvimento cognitivo e sua condução intencional. Desta forma, a boa aprendizagem precisa estar avançada em relação ao desenvolvimento. Sendo assim, a aprendizagem orientada para níveis de desenvolvimento já alcançados não é efetiva, do ponto 
de vista do desenvolvimento cognitivo do aprendiz. A função do professor como mediador na aquisição de significados contextualmente aceitos é indispensável, pois realiza o intercâmbio de significados por atuação na zona de desenvolvimento proximal do aluno. A origem social das funções mentais superiores colabora na compreensão da estrutura do conhecimento. Por exemplo, o processo de ensino-aprendizagem escolar é caracterizado pela interação social entre professor e classe, sendo o professor o participante que já internalizou os significados socialmente compartilhados que compõe o currículo. O aluno responde por meio de algum mecanismo a ação do professor evidenciando o significado que captou. Assim, o professor fica responsável por verificar se o significado que o aluno captou é compatível com o compartilhado socialmente e ao aluno cabe verificar se os significados que captou são equivalentes a aqueles compartilhados no contexto da área de conhecimentos em questão. O ensino e a aprendizagem se consolidam quando aluno e professor compartilham significados. Contudo não se pode deixar de salientar que nesse processo o professor também aprende, na medida em que clarifica ou incorpora significados à sua organização cognitiva. Todavia, ainda está em posição distinta do aluno no que se refere ao domínio de instrumentos, signos e sistemas de signos, contextualmente aceitos.

Nesse cenário onde o intercâmbio de significados mobiliza a aprendizagem não fica evidente como ocorre a internalização dos conceitos; todavia, deixa claro que esse intercâmbio é mister para a aprendizagem. Sem interação social, ou sem intercâmbio de significados, dentro da zona de desenvolvimento proximal do aprendiz, não ocorre ensino, nem aprendizagem e tampouco desenvolvimento cognitivo. Todos os envolvidos no processo ensino-aprendizagem devem ter oportunidade de se expressar a respeito das questões em voga. A mudança conceitual é claramente interpretável nessa perspectiva: implica internalização de novos significados, delimitação do foco, talvez abandono de ideias e possível coexistência de significados. Enfim, um processo complexo, em movimento, com vários substratos contextuais os quais tem dependência vital da interação social e intenso intercâmbio de significados.

As questões observadas sobre o processo de ensino-aprendizagem como fruto de uma interação social orientada fornece subsídios a prática do professor e indica que a utilização do ambiente é fundamental à sua ação docente. Desta forma, a compreensão de questões relativas ao processo pode ser melhor observada e fornecer mecanismos para uma organização de sequências didáticas ativas e efetivas. 


\subsection{Ensino por Habilidades e Competências no Sis- tema Colégio Militar}

O Sistema de Ensino do Exército, é coordenado pelo Departamento de Educação e Cultura do Exército (DECEx), tendo a Diretoria de Educação Preparatória e Assistencial (DEPA) como subordinada e responsável pela coordenação e supervisão dos procedimentos da educação básica junto aos 13 (treze) Colégios Militares (CM), os quais compõem o Sistema Colégio Militar do Brasil (SCMB). Na esfera da DEPA e CM's foram elaborados os novos currículos e documentos que dão suporte à prática docente orientada para abordagem de Ensino por Competências, tais determinações estão baseadas na legislação vigente (LDBEN, DCN, PCN, PCN+ ...). [16]

As ações didático-metodológicas estão orientadas para a formação do aluno do Colégio Militar de acordo com a legislação vigente (Lei de Diretrizes e Bases da Educação Nacional - LDBEN e Parâmetros Curriculares Nacionais - PCN), considerando o perfil etário, afetivo e cognitivo de seu público e a finalidade de sua missão. Os termos competências e habilidades constam nos PCN desde 1998, no intuito de transformar a ação pedagógica da escola tradicional em uma nova atitude educativa procedida por uma escola moderna. Esse movimento se caracteriza por modificar o ensino propedêutico e conteudista o qual conduzia os alunos a realizar uma mera memorização dos conteúdos em uma prática docente dinâmica e ativa que fomenta uma atitude consciente capaz de estimular a crítica e inventiva do estudante.

Nesta proposta, a ação recebe bastante ênfase, na medida em que a escola vai partir das motivações e conhecimentos prévios dos alunos, em detrimento de conceitos estabelecidos ad hoc, para fazê-los encontrar um significado nos conteúdos. A aprendizagem e a aplicabilidade do conhecimento ficam mais claras para o aluno que passa a sentir-se motivado ao identificar a finalidade do que está aprendendo.

Nesse sentido a atividade metodológica é estabelecida a partir de cinco eixos cognitivos:

- Dominar linguagens (DL): dominar a norma culta da Língua Portuguesa e fazer uso das linguagens matemática, artística e científica.

- Compreender fenômenos $(\mathrm{CF})$ : construir e aplicar conceitos das várias áreas do conhecimento para a compreensão de fenômenos naturais, de processos histórico-geográficos, da produção tecnológica e das manifestações artísticas. 
- Enfrentar situações -problema (SP): selecionar, organizar, relacionar, interpretar dados e informações representados de diferentes formas, para tomar decisões e enfrentar situações -problema.

- Construir argumentação (CA): relacionar informações, representadas em diferentes formas, e conhecimentos disponíveis nas situações, para construir argumentação consistente.

- Elaborar propostas (EP): recorrer aos conhecimentos desenvolvidos na escola para elaboração de propostas de intervenção solidária na realidade, respeitando os valores humanos e considerando a diversidade sociocultural.

As teorias cognitivistas da aprendizagem, principalmente as de Piaget e Ausubel, foram as bases para definição desses eixos cujos enfoques repousam na ancoragem ao conhecimento prévio dos alunos, no uso de "organizadores prévios" no estabelecimento de "pontes cognitivas" para que o aluno, de fato, possa desenvolver toda a estrutura cognitiva desenhada no caminho a ser percorrido pelos cinco eixos. Os parâmetros descrevem o trabalho com as competências apontando sempre para o desenvolvimento do que ele chama de arquicompetências, o desenvolvimento da leitura e da escrita em todas as disciplinas, assim como para um trabalho inter/multi e transdisciplinar e contextualizado. A principal mudança, portanto, reside na forma de ensinar. Partindo da premissa que o aluno necessita de um conhecimento interdisciplinar, do domínio das linguagens que modelam cada disciplina e da capacidade de resolver situações-problema cujas resoluções dependam do envolvimento com o conhecimento e metodologias empregadas. Assim, é necessário que o currículo e as avaliações sejam condizentes com esse enfoque.

O conceito de Conhecimento Prévio, bastante difundido e ampliado por diferentes pesquisas e linhas teóricas, torna-se de fundamental importância na prática docente. O trabalho de pesquisadores consagrados na Educação, Psicologia, Linguística, entre outros, apontam que o professor deve iniciar a abordagem de um conteúdo pela identificação dos elementos que os alunos trazem consigo do tema em questão. Perceber o que sua turma efetivamente conhece sobre o que será tratado fornece um substrato a ser transformado apropriadamente. Assim, a busca do conhecimento prévio é o início de um processo que se destina a tornar a aprendizagem significativa a qual subsidia o ensino que empreende no desenvolvimento de habilidades e competências.

A abordagem do Ensino por Competências promove o repensar das práticas educa- 
cionais de modo a contribuir para a formação do cidadão por meio do desenvolvimento de quatro grandes pilares segundo Delors [17]:

Aprender a conhecer, combinando uma cultura geral, suficientemente ampla, com a possibilidade de estudar, em profundidade, um número reduzido de assuntos, ou seja: aprender a aprender, para beneficiar-se das oportunidades oferecidas pela educação ao longo da vida.

Aprender a fazer, a fim de adquirir não só uma qualificação profissional, mas, de uma maneira mais abrangente, a competência que torna a pessoa apta a enfrentar numerosas situações e a trabalhar em equipe. Além disso, aprender a fazer no âmbito das diversas experiências sociais ou de trabalho, oferecidas aos jovens e adolescentes, seja espontaneamente na sequência do contexto local ou nacional, seja formalmente, graças ao desenvolvimento do ensino alternado com o trabalho.

Aprender a conviver, desenvolvendo a compreensão do outro e a percepção das interdependências realizar projetos comuns e preparar-se para gerenciar conflitos no respeito pelos valores do pluralismo, da compreensão mútua e da paz.

Aprender a ser, para desenvolver, o melhor possível, a personalidade e estar em condições de agir com uma capacidade cada vez maior de autonomia, discernimento e responsabilidade pessoal. Com essa finalidade, a educação deve levar em consideração todas as potencialidades de cada indivíduo: memória, raciocínio, sentido estético, capacidades físicas, aptidão para comunicar-se.

A fim de realizar uma formação nessa perspectiva, os conteúdos e as atividades de ensino são organizados solidários a realidade dos alunos. Desta forma, podem ser observados, analisados, experimentados, de tal maneira que possam realizar intervenção e reflexão sobre a realidade na qual os estudantes vivem. Portanto, os conteúdos agora 
denominados objetos do conhecimento devem ser meios para conhecer ou responder a questões de uma realidade experiencial estabelecida.

A compreensão da proposta de ensino-aprendizagem desenvolvida pelo Sistema Colégio Militar de Ensino perpassa pelo entendimento da metodologia de Ensino por Competências. Desta forma é fundamental reconhecer os conceitos chave, para, posteriormente, estabelecer uma vinculação entre todos estes.

\section{Conceito de Habilidade:}

São os meios pelos quais se pretende atingir os objetivos de um processo, ou seja, devem ser desenvolvidas e mobilizadas em busca de competências. As habilidades são elementos manifestamente associados ao saber fazer: exercício de uma ou mais ações, físicas ou mentais que indicam capacidades adquiridas, exemplos:

- Identificação de variáveis;

- Compreenção de fenômenos;

- Relacionar informações;

- Analisar situações-problema;

- Elaboração de síntese;

- Exercer julgamento;

- Correlacionar conceito e ideias, entre outras.

O aluno desenvolve as habilidades através dos conteúdos e exercitando as habilidades adquire a competência.

\section{Conceito de Competência:}

Proposto por Perrenoud [18], tal conceito deve ser compreendido como a

"Faculdade de mobilização de um conjunto de recursos cognitivos como saberes, habilidades e informações para solucionar com pertinência e eficácia uma série de situações."

O autor concebe que as competências devem articular: 
- Conhecimentos

- Procedimentos

- Habilidades

- Atitudes

- Valores

Desta forma, trabalhar no desenvolvimento de habilidades que fomentem competências em cada área do conhecimento modifica a prática pedagógica do professor na Escola Tradicional, deslocando a ênfase para a ação em relação a teoria. Assim, possibilita que os alunos encontrem significados palpáveis nos conteúdos escolares, à medida em que a prática docente considera o cotidiano como parte da motivação e não de conceitos previamente estabelecidos.

Essas características de ensino no Sistema Colégio Militar do Brasil são completamente compatíveis com as abordagens realizadas na Teoria de Ausubel e no Sócio-Interacionismos de Vygotsky. Portanto, utilizar uma sequência didática cujo escopo teorico sejam tais Teorias de Aprendizagem não contradiz a filosofia de ensino do sistema. 
Capítulo 3

\section{Sequências Didáticas para abordagem do Movimento Harmônico Simples, Interferência e Efeito Doppler}

Neste capítulo, vamos apresentar a estrutura básica de uma Unidade de Ensino Potencialmente Significativa destacando suas características em relação as Teorias de Aprendizagem. Serão abordados de forma resumida os estágios de uma UEPS e qual a contribuição da teoria da aprendizagem pode ser identificada na fase do processo. O intuito de realizar essa revisão se deve pela a estrutura das Sequências Didáticas propostas nesse trabalho se aproximarem de UEPS. Posteriormente, apresentamos a Sequência Didática criada para a abordagem do Movimento Harmônico Simples destacando suas peculiaridades. Em seguida, mostramos a Sequência Didática que foi elaborada a fim de discutir o Fenômeno de Interferência em Ondulatória destacando os elementos da metodologia. Por fim, abordamos a Sequência Didática construída para realizar as observações sobre frequência de uma onda e do Efeito Doppler.

\subsection{Síntese de uma Unidade de Ensino Potencial- mente Significativa}

No capítulo anterior foi observado que as Teorias de Ausubel e Lev-Vygotsky fornecem elementos fundamentais para elaboração de um processo de ensino-aprendizado mais robusto e efetivo em relação aqueles utilizados no ensino tradicional. Nesse 
sentido algumas metodologias vem se destacando entre os professores que adotam uma nova postura na condução de sua prática docente. Entre essas, a utilização de Unidades de Ensino Potencialmente Significativas (UEPS) tem se consolidado e demonstrado resultados efetivos no ensino de Física de forma que se difunde em larga escala nos programas de pós-graduação em ensino de Física.

A elaboração e execução de uma UEPS, para ser bem-sucedida, precisa ser intencional, ou seja, ocorre um compromisso mútuo entre docente e discente os quais devem estar dispostos a esse empreendimento. Assim, é necessário existir no professor a intenção de modificar sua prática pedagógica para o resultado de uma UEPS ser positivo. Isto acontece à medida que o docente compreende que é mister abandonar o algoritmo de ensino de Física por resolução de problemas repetitivos. A abordagem do Fenômeno Físico é fundamental, impedindo a estratificação do objeto do conhecimento o que é influenciado pelo livro didático o qual deve ser utilizado como um instrumento auxiliar e não fundamental. Assim, a caracterização da Física como algo segmentado, o que fornece uma ideia de Ciência acabada e imutável, pode ser evitada [19]. O docente que é alheio às pesquisas em ensino de física ou mesmo que acredita no programa tradicional precisa colocar em dúvida suas convicções e procurar instrumentos e meios de aperfeiçoamento profissional.

Além disso, para o sucesso da UEPS, deve ser realizada uma seleção apropriada do tema. A extensão da atividade não deve proporcionar uma utilização de tempo inapropriada o que pode causar a perda de noção de um processo em execução. Essa questão é crítica, pois um problema comum no currículo escolar em relação a disciplina de Física é a grande quantidade de conteúdos e a carga horária da disciplina que vem sendo continuamente reduzida. Assim, proceder uma seleção de assuntos sem a preocupação de satisfazer o anseio do livro didático, o qual é o baluarte do ensino tradicional, torna-se uma medida indispensável para a formulação da UEPS.

No intuito de sintetizar o arcabouço teórico de uma Unidade de Ensino Potencialmente Significativa foi elaborada uma Matriz que evidencia a contribuição de cada Teórico da Aprendizagem no processo de elaboração de uma UEPS (figura 3.1). Constata-se que a participação de M. A. Moreira deixa claro os critérios para se determinar quando uma aprendizagem é reconhecida como significativa. Nesse sentido introduz o conceito de abordagem de situações inéditas para validação da aprendizagem significativa, além de destacar a necessidade de surgir, por parte do aprendiz, questionamentos a respeito das observações realizadas procurando alcançar melhor compreensão do conceito. 


\begin{tabular}{|c|c|c|c|c|c|c|c|c|c|c|c|c|c|c|}
\hline $\begin{array}{|cc|} & \frac{\pi}{0} \\
& \frac{0}{2} \\
& 0 \\
\end{array}$ & & & & & & & & & & & & & 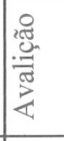 & 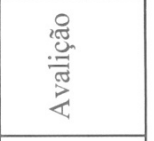 \\
\hline 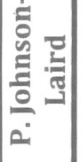 & & & & & & 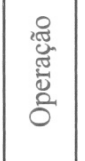 & & & & & & & & \\
\hline 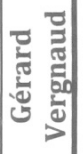 & & & & & 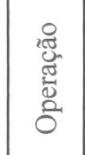 & & & & 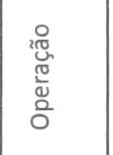 & & & & & \\
\hline 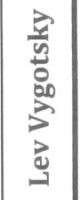 & & & & & & & & & & 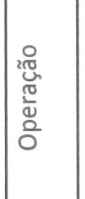 & & & & \\
\hline $\begin{array}{l}0 \\
0 \\
0 \\
0 \\
0 \\
0 \\
0\end{array}$ & & 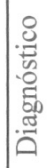 & & & & & & & 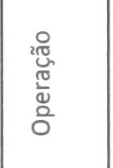 & 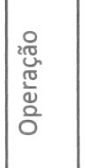 & 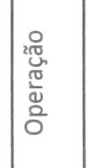 & & & \\
\hline 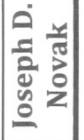 & & & & & & & & & & & & 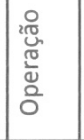 & & \\
\hline 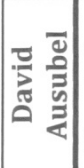 & 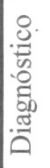 & 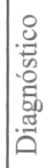 & 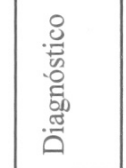 & 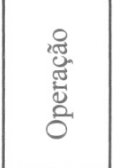 & & & 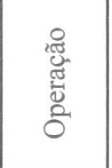 & 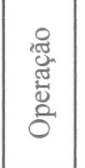 & & & & & & \\
\hline & & & & ва!рв & 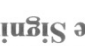 & эұшәші & |в!эuә̨о d & ou!su & U' әр әр & orp!u & ( ир аs & $\mathbb{B}_{\boldsymbol{H}}$ & & \\
\hline 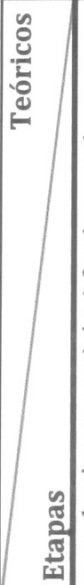 & 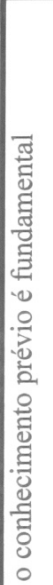 & 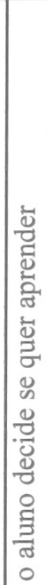 & 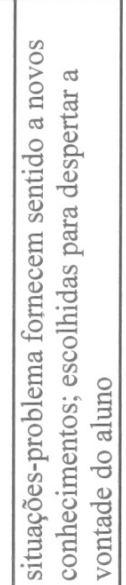 & 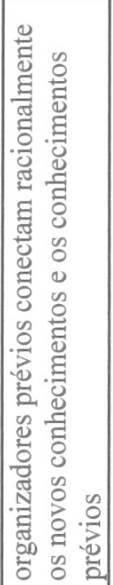 & 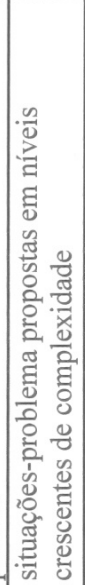 & 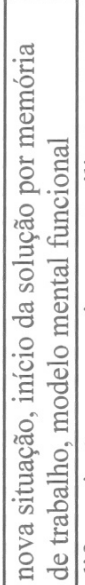 & 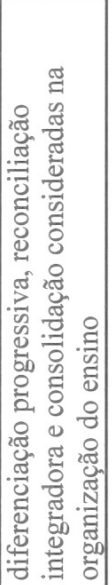 & 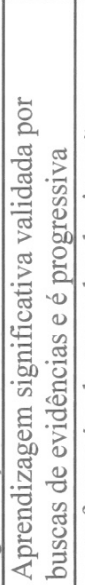 & 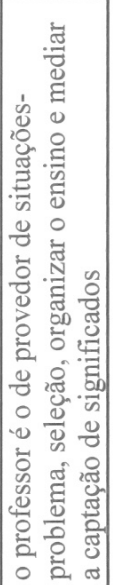 & 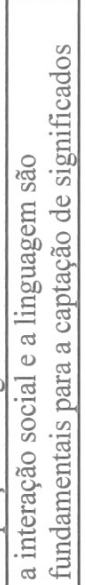 & 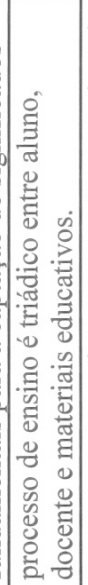 & 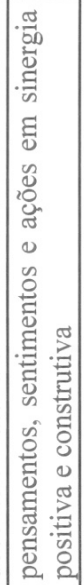 & 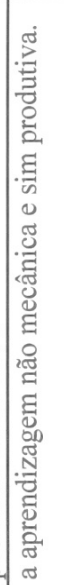 & 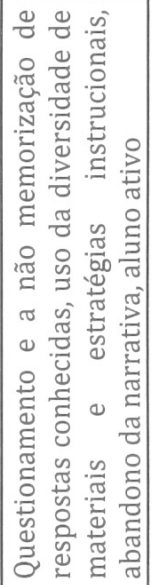 \\
\hline
\end{tabular}

Figura 3.1: Matriz Teórica de uma UEPS 
Na Matriz (figura 3.1) é mostrado que uma UEPS aproveita o trabalho dos diferentes autores em momentos específicos do processo os quais podem ser elencados como diagnóstico, operação e Avaliação. Isto mostra a necessidade de um domínio mínimo necessário das teorias de aprendizagem para elaborar e aplicar uma UEPS.

\subsection{O movimento hamônico simples por meio de uma quase-UEPS}

A compreensão do movimento hamônico simples pelos estudantes do segundo ano do ensino médio apresenta grande dificuldade em virtude de sua descrição matemática depender de funções trigonométricas. O significado dessas funções geralmente são deficientes, pois são apresentadas sem nenhum contexto quando abordadas por professores de matemática. A fim de contornar essa barreira cognitiva apresentamos uma proposta de sequência didática com alguns elementos de uma UEPS (quaseUEPS). Num primeiro momento utiliza-se um vídeo capaz de ser organizador prévio que contextualize o fenômeno oscilatório e traga consigo subsunçores claros para o professor conduzir sua prática. Posteriormente, é aplicado um simulador para explicitar a estrutura matemática que descreve o movimento hamônico simples. Em seguida, por meio de outra simulação computacional, mostramos diferentes objetos que realizam tal movimento. Por fim, realizamos uma simples prática de laboratório capaz de caracterizar uma utilidade fundamental do movimento hamônico simples.

\section{Vídeo como organizador prévio}

O primeiro elemento da sequência didática se constitui de um vídeo onde é apresentada uma máquina a vapor em funcionamento e serve de situação-problema sim-

plificada. Recomenda-se utilizar o vídeo disponível no site www.youtube.com pelo endereço https: //www.youtube.com/watch?v=oWt7fHbLx30.

No situação do vídeo a máquina é colocada em funcionamento pela combustão de uma substância, de forma que se pode observar o movimento do mecanismo. Após os estudantes assistirem o vídeo serão submetidos a uma série de indagações (Apêndice A) a fim do professor realizar um diagnóstico e simultaneamente instigar os alunos sobre o fenômeno observado de forma interativa e mediada. 


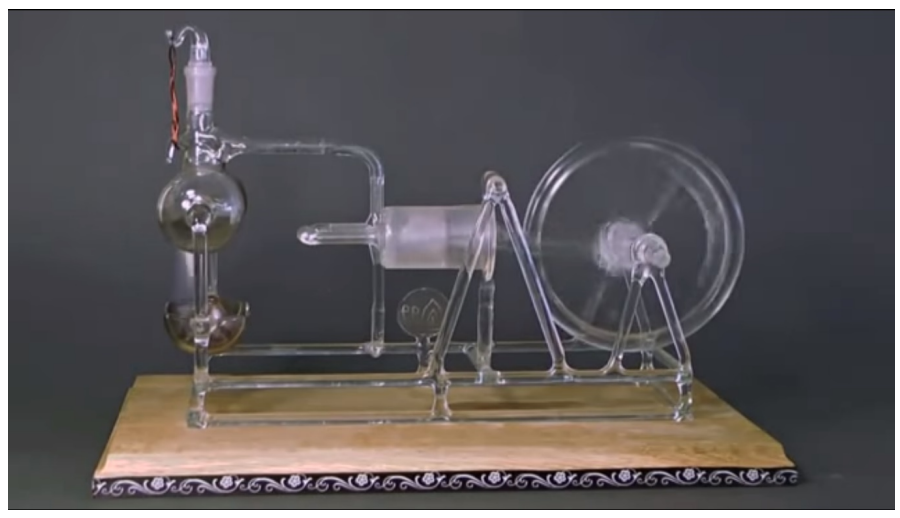

Figura 3.2: Máquina a Vapor de Vidro

\section{Software Modellus e a Diferenciação progressiva}

Após consolidar os dados do questionário no intuito de entender a percepção dos discentes o professor faz a abordagem dos movimentos da roda e do pistão da máquina a vapor por meio do software livre Modellus $X$ (Figura 3.3) disponível no site http://modellus.co/index.php?lang=pt. O download do programa e sua instalação são simples, requerendo poucos conhecimentos de informática, o que sugere ao professor que oriente seus alunos a instalarem o software em seu computador pessoal a fim de refazerem a tarefa em casa.

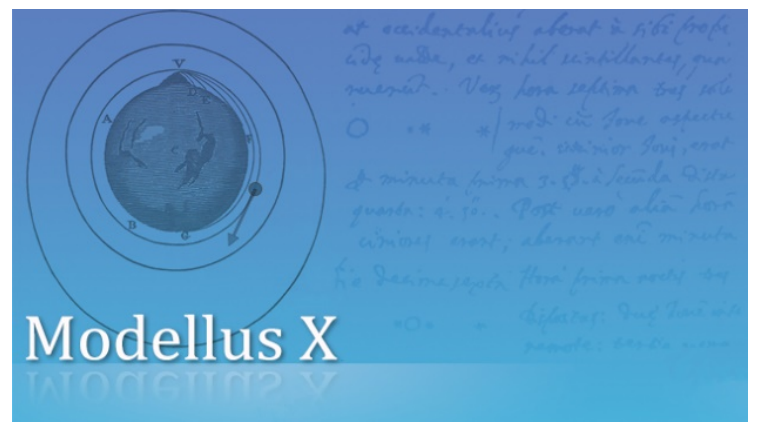

Figura 3.3: Abertura do software Modellus X

Em sala de aula o docente apresenta a forma de simular os movimentos das partes da máquina a vapor por meio do software. Nessa discussão, caracteriza o movimento da roda na máquina a vapor ressaltando a utilização das funções trigonométricas e cada parâmetro significativo: ângulo, amplitude, frequência, velocidade... Faz o destaque de como as coordenadas do objeto servem para realizar a descrição do movimento circular (figura 3.4). 


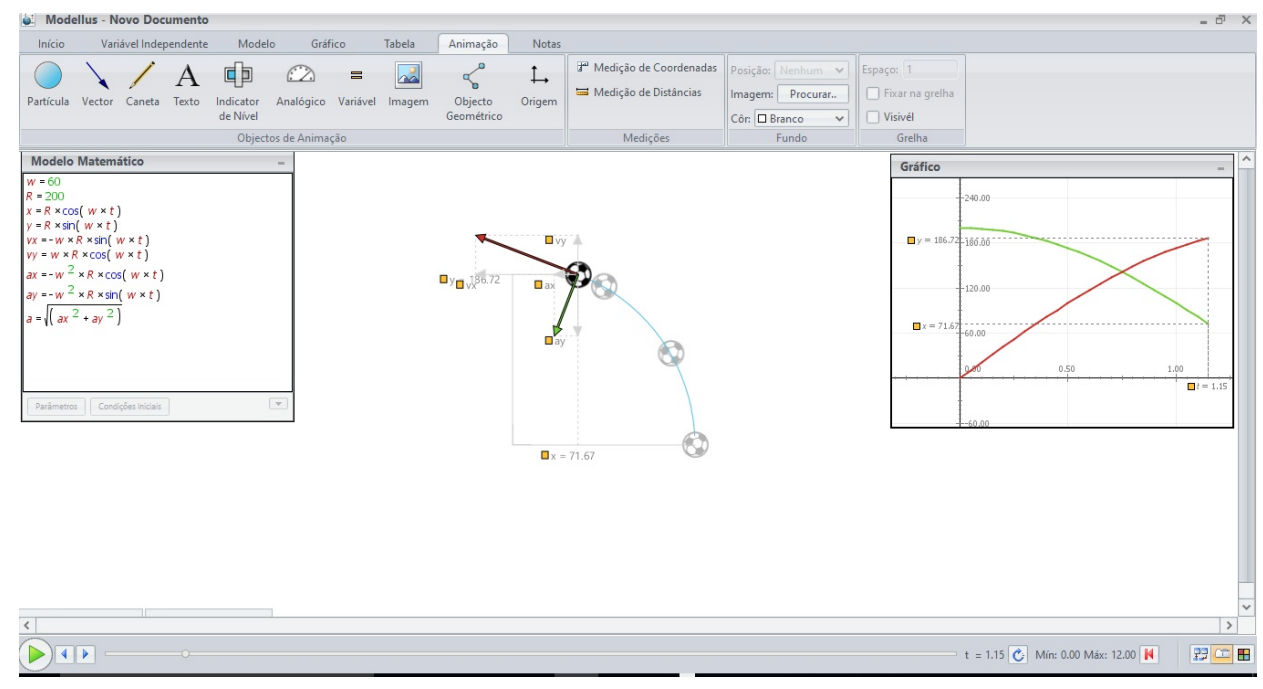

Figura 3.4: Tela de configuração para simulação do movimento circular

Desta maneira, espera-se que o discente em sua estrutura cognitiva esteja realizando a ancoragem dos conceitos de funções trigonométricas ao subsunçor movimento circular. Por se tratar de uma ampliação dos conceitos subsunçores ocorre uma diferenciação progressiva. Em seguida, o professor introduz outro objeto na simulação associando o movimento harmônico simples (MHS) com uma projeção do movimento circular (figura 3.5).

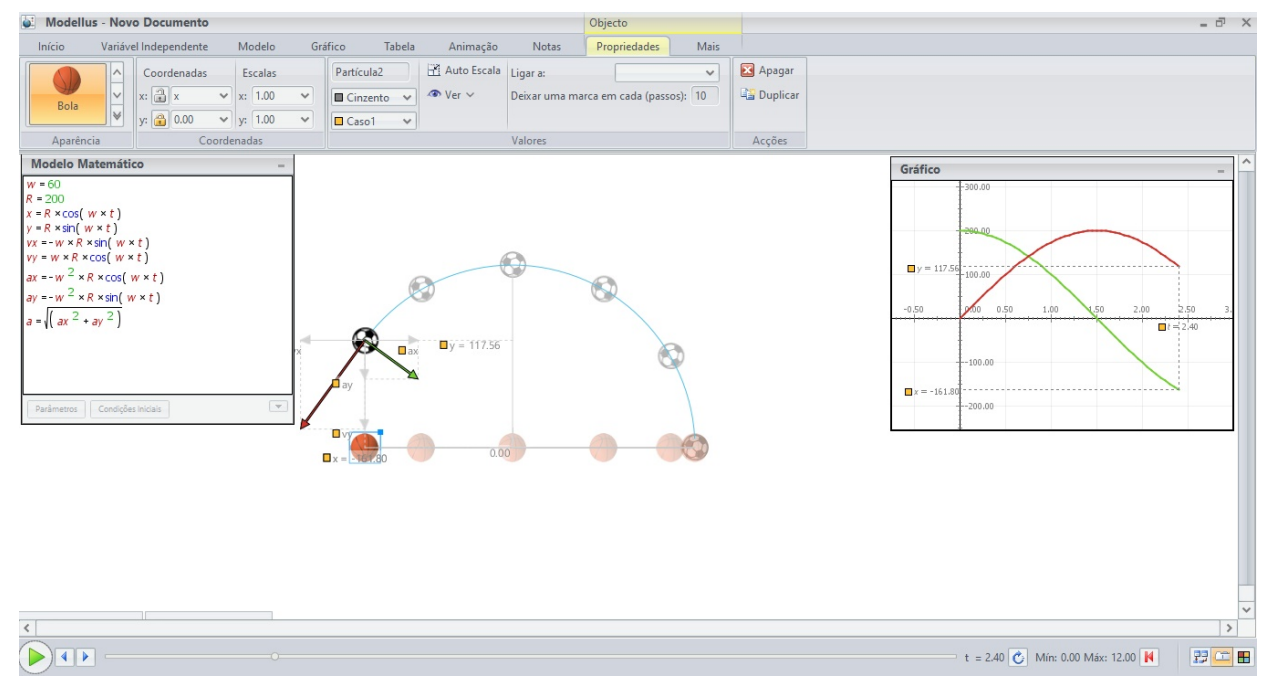

Figura 3.5: Movimento circular e sua projeção

Assim aborda conceitos do MHS como fase inicial, amplitude e pulsação por meio da posição do objeto oscilante em relação ao centro do círculo. 


\section{Aula ativa como reconciliação integrativa}

Ao prosseguir com a discussão deve mobilizar conceitos já conhecidos: força elástica, energia potencial elástica, energia cinética, conservação de energia; a fim de realizar uma reconciliação integrativa por meio da recombinação desses elementos no contexto do movimento harmônico simples. O software comercial Newton, figura 3.6, que trabalha como um laboratório virtual, dispõe de um módulo capaz de relacionar esses elementos com vários dispositivos que apresentam distintos movimentos.

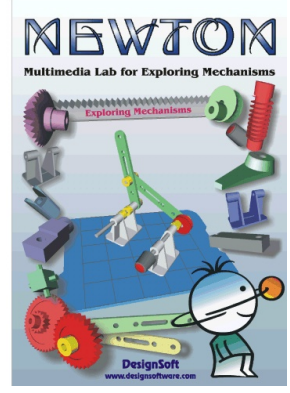

Figura 3.6: Software comercial Newton

Desta forma, pode abordar que a dinâmica do movimento harmônico simples se manifesta no sistema massa-mola e também no pêndulo. Sendo assim, é possível se caracterizar conceitos como amplitude e frequência por meio da visualização do movimento de tais objetos no software Newton (figura 3.7).

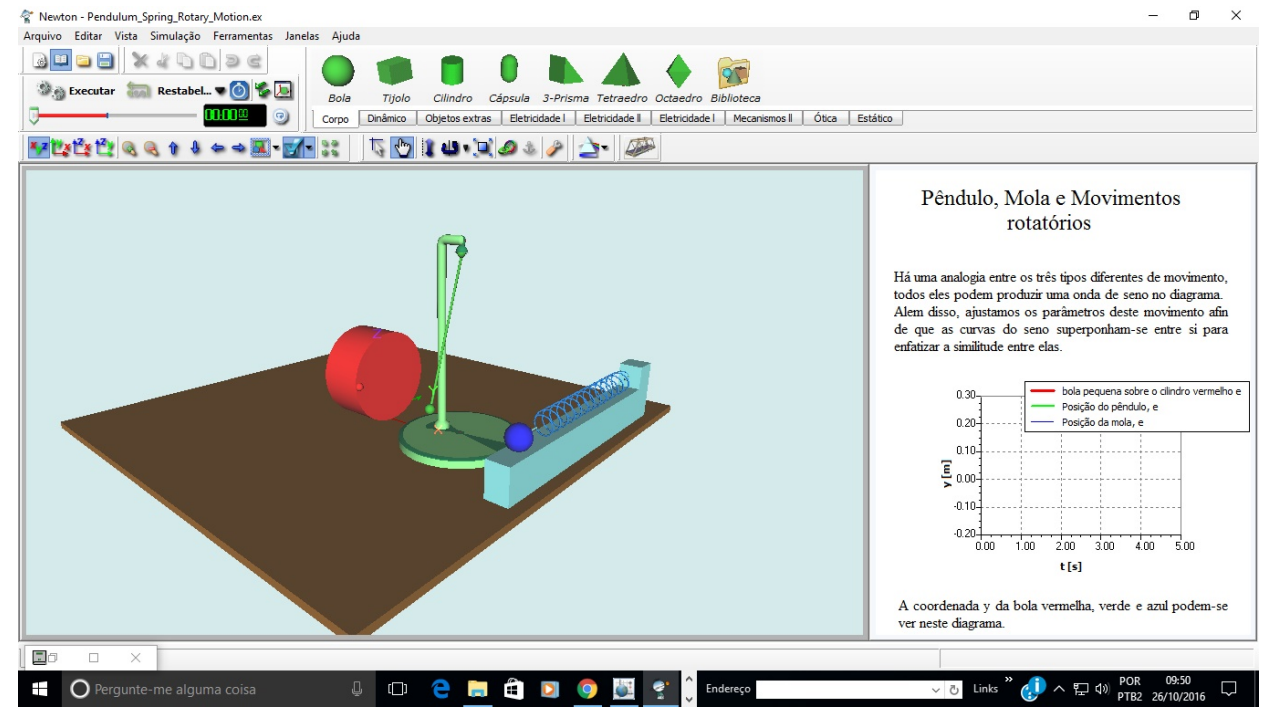

Figura 3.7: Sistema massa-mola, pêndulo e corpo girante no software Newton 
A manipulação dos objetos nesse laboratório virtual proporciona a realização da reconciliação integrativa dos conceitos da dinâmica no movimento harmônico simples.

\section{Utilização da prática a fim de consolidar a mediação e comunicação}

O último elemento da condução da sequência didática próxima de uma UEPS ocorre no laboratório. Utilizando um roteiro orientador, presente no Apêndice B, os estudantes, em grupos, realizam algumas simples práticas a fim de obter os valores da aceleração da gravidade por meio do pêndulo e variação de suas características. Nesse momento fica evidente a consolidação da interação entre alunos e professor de maneira que os primeiros estão exercendo a atividade de forma ativa e colaborativa.

\subsection{O efeito de interferência em ondas utilizando ele- mentos de UEPS}

O fenômeno de interferência certamente é um dos efeitos mais característicos da ondulatória. Sua compreensão fornece indícios sobre a capacidade dos estudantes em identificar objetos que manifestam o comportamento ondulatório, o qual está presente numa gama variada de aplicações e construções teóricas. Assim, a sequência didática proposta mobiliza uma série de instrumentos orientados que podem proporcionar uma aprendizagem significativa. Iniciamos com um vídeo que ilustra o efeito de interferência em duas dimensões, depois abordamos sua descrição por meio de um software capaz de destacar vários aspectos de uma onda, em seguida analisamos a interferência de ondas em uma superfície realizando uma comparação com o mesmo efeito produzido por ondas sonoras também por meio de simulações.

\section{Vídeo como organizador prévio}

Ao abordar esse assunto os alunos detém alguns conceitos subsunçores do tema pois o professor já apresentou o que é uma onda e suas características gerais: propagação, efeitos de reflexão e superposição em meios unidimensionais como uma corda. Assim, utilizando a filosofia do produto educacional, foi selecionado um vídeo que aborda o assunto de maneira que seja um organizador prévio. Novamente indicamos o site www.youtube.com como fonte e destacamos o vídeo, figura 3.8, que pode ser 
acessado pelo endereço https://www.youtube.com/watch?v=Po4JREyUDYc.

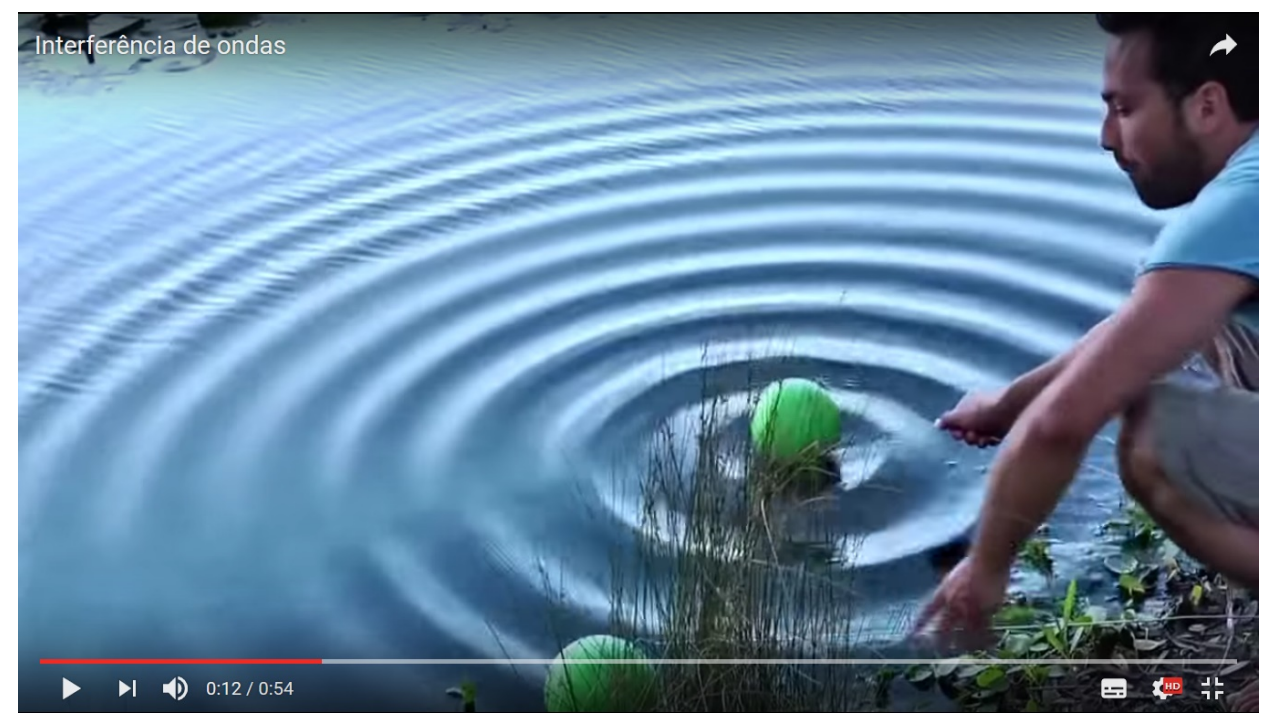

Figura 3.8: Propagação de ondas na superfície de um lago.

Nessa filmagem, o apresentador destaca o padrão de propagação de uma onda produzida por uma única fonte destacando o formato circular que se origina. Em seguida, introduz outra fonte de ondas que produz mudanças perceptíveis nas frentes de ondas que se propagam na superície do lago.

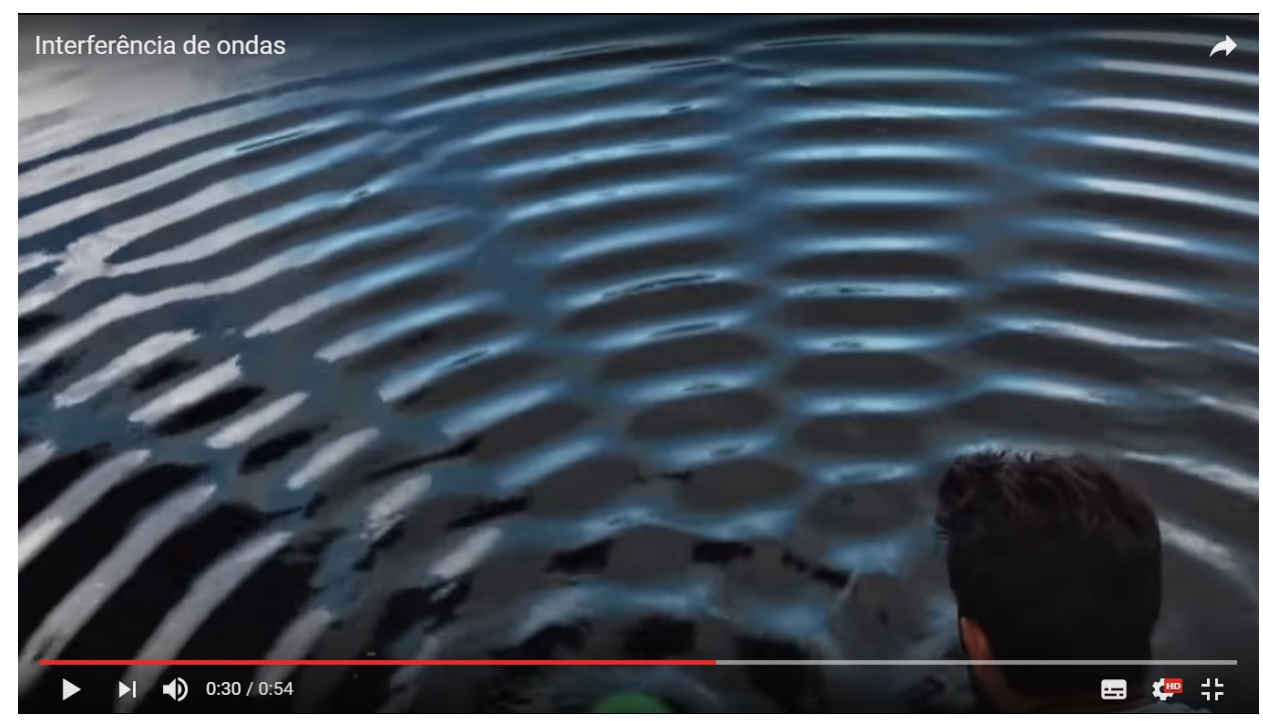

Figura 3.9: Interferência em ondas na superfície de um lago.

Em virtude de se tratar de um objeto do conhecimento seleto que se insere num momento mais geral é proposta uma aplicação de perguntas diagnósticas para com- 
preensão e elaboração de subsunçores, apêndice A. Desta forma, o professor deve expor o assunto ativando os alunos e seus conhecimentos prévios, fazer anotações e provocar inquietação nos discentes a fim de expressarem suas percepções. Assim, poderão perceber coletivamente, pela mediação do professor, a diferença no resultado de superposição de ondas em fase a qual produz interferência construtiva em comparação com a superposição de ondas em oposição de fase que produz interferência destrutiva.

\section{Software Ondas e a Diferenciação progressiva}

A fim de manipular o fenômeno de maneira controlada o professor deve realizar nova abordagem utilizando o software gratuito Ondas, disponível para download em http://www.xente.mundo-r.com/explora/ondas/ondas-es.htm, o qual pode ser utilizado para rever as características de ondas unidimensionais: comprimento, amplitude, frequência entre outros; e destacar as características de interferência.

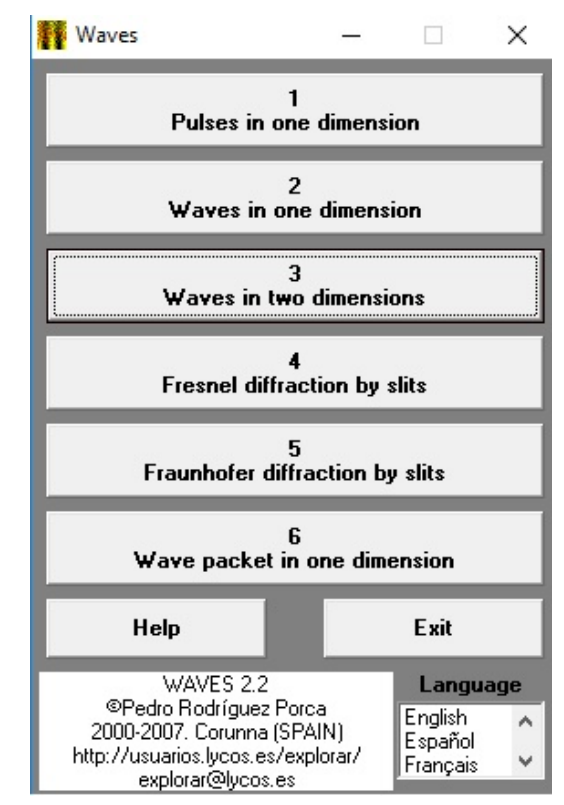

Figura 3.10: Tela inicial do software Ondas.

No caso de ondas bidimensionais o software permite realizar variações das posições das fontes, amplitude e diferença de fase. O padrão de interferência pode ser verificado e analisado conforme a figura 3.11. Desta forma, o software se torna um instrumento manipulável de bastante utilidade para proporcionar compreensão do fenômeno e 
assim exercer a diferenciação progressiva dos subsunçores na estrutura cognitiva do aprendiz.

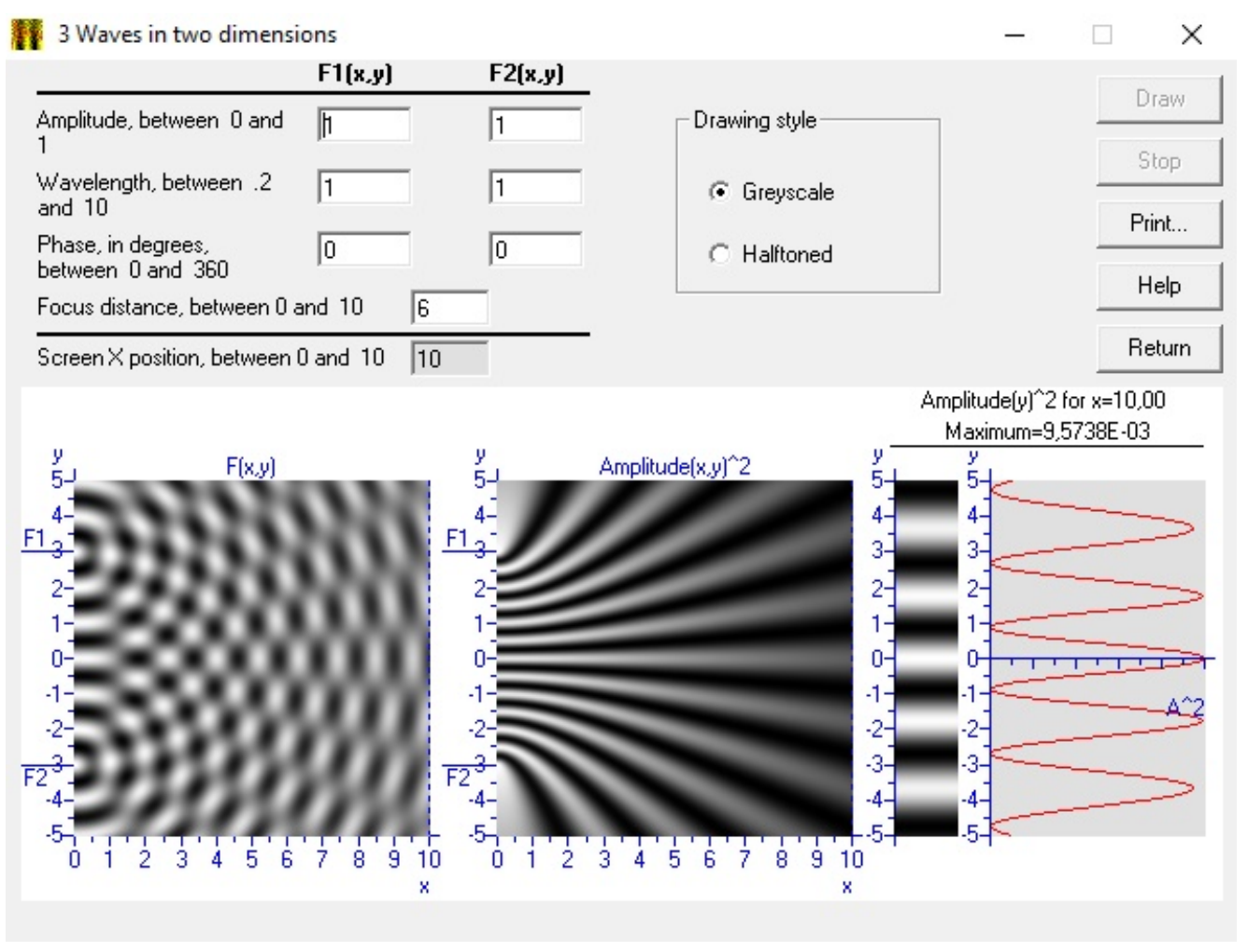

Figura 3.11: Padrão de interferência em superfícies.

\section{A utilização do simulador PhET a fim de realizar reconciliação integrativa}

Após algumas aulas ativas onde é detalhada a matemática que descreve o fenômeno de interferência em ondas bidimensionais se faz necessário o retorno a visulização do efeito a fim de se realizar a reconciliação integrativa entre ondas se propagando na superfície de um lago e ondas sonoras na atmosfera. Tal procedimento é útil pois fornece a preparação de subsunçores para o emprego da última sequência didática, a qual finaliza o produto de ensino proposto. Assim, a utilização do simulador PhET, produzido pela universidade do Colorado, disponível no site https://phet.colorado.edu/en/simulations/category/physics/sound-andwaves, para download de forma gratuita, é bastante apropriada. Num primeiro momento simulamos ondas numa superfície d'agua originadas pelo gotejar de uma torneira. 


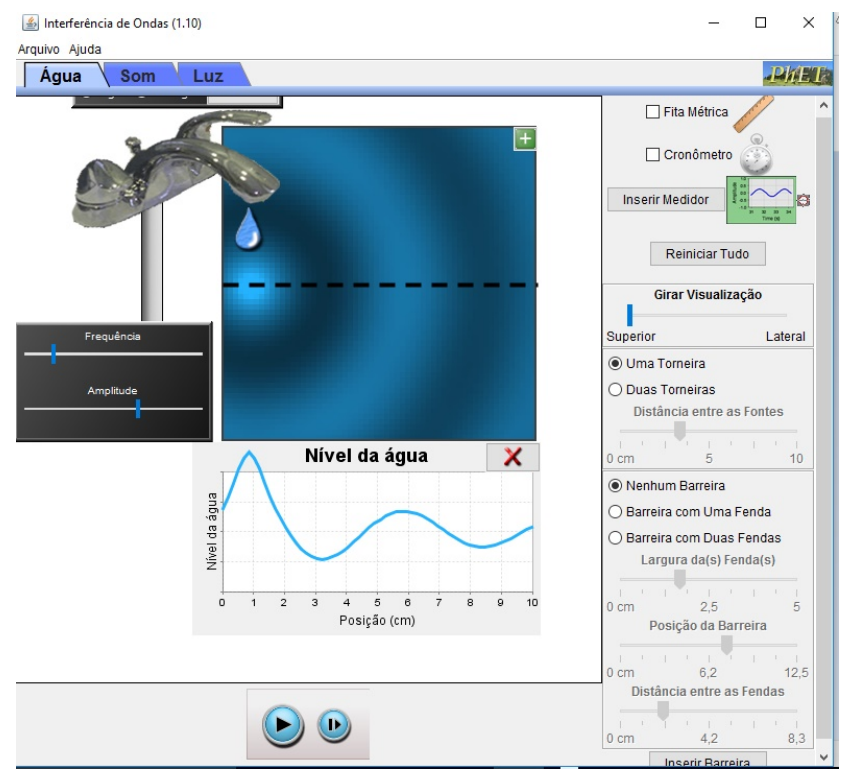

Figura 3.12: Propagação da onda em superfície.

Na simulação se percebe que a frequência da onda gerada é igual a do gotejamento que é a fonte da perturbação, destacando a assertiva que a frequência de uma onda depende da frequência da fonte. Depois, inserimos outra torneira no intuito de obter o padrão de interferência pela superposição de frentes de onda (figura 3.13).

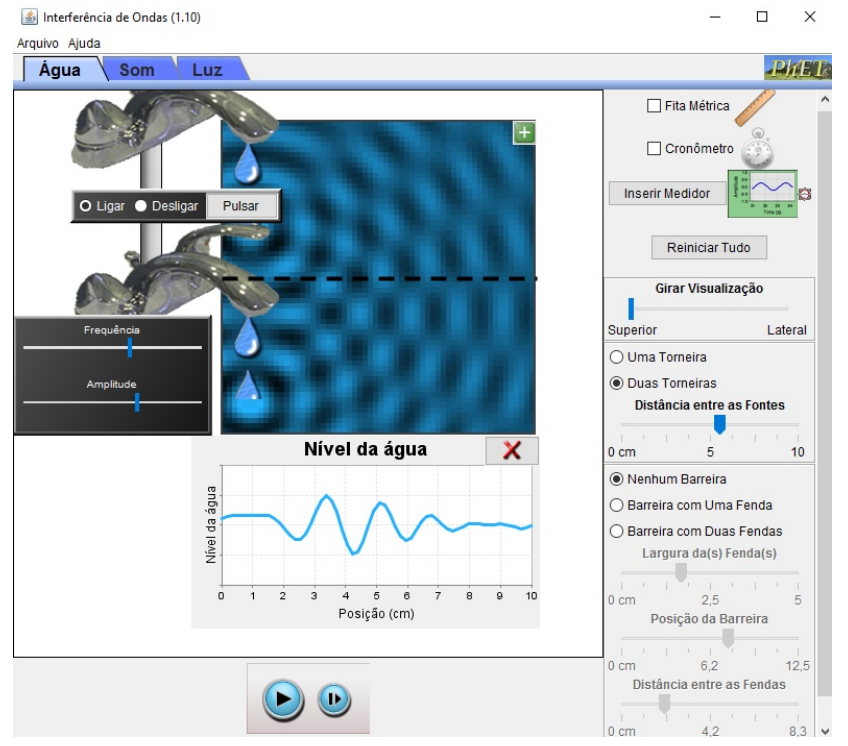

Figura 3.13: Interferência na propagação de onda em superfície.

Assim, pode-se comparar esse padrão com o obtido pela simulação de ondas so- 
noras produzidas por dois alto-falantes (figura 3.14) destacando as regiões de interferência constutiva e destrutiva pelo movimento da figura que representa o ouvinte.

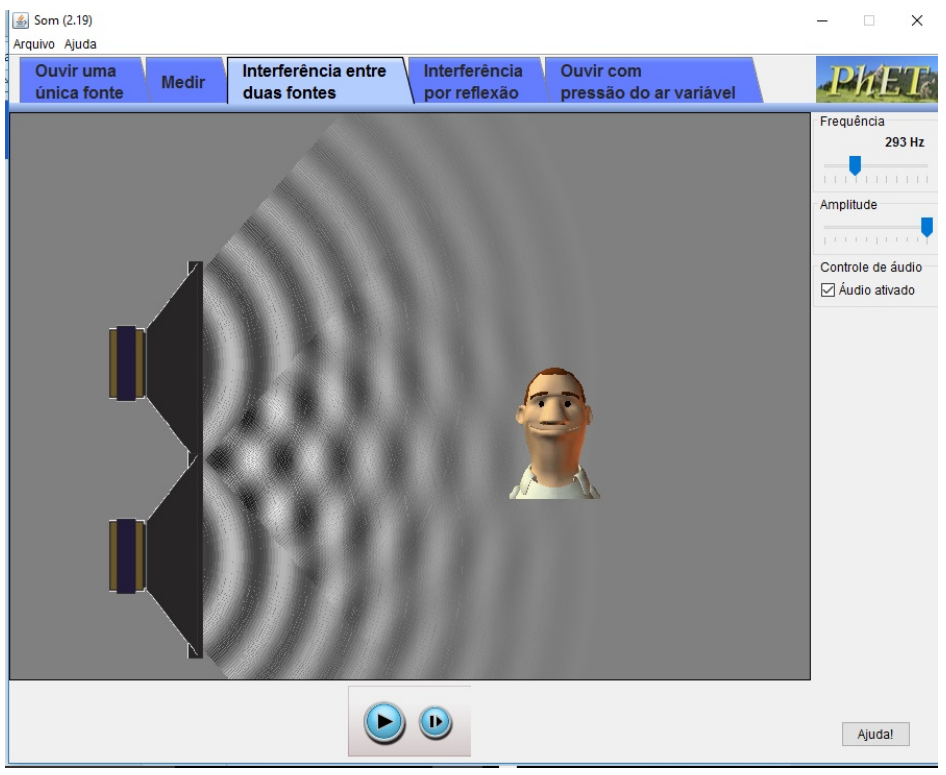

Figura 3.14: Interferência na propagação de onda sonora.

Por fim, deve ser destacada que a frequência da onda sonora poder ser entendida de maneira semelhante a frequência de uma onda na superfície d'agua, de forma que esse momento é aproveitado para se inserir subsunçores utilizados na próxima sequência didáica.

\subsection{Abordagem do efeito Doppler por uma UEPS modificada}

Um dos elementos mais característicos de uma onda é a frequência, tal propriedade está relacionada a vários efeitos: sensações fisiológicas, batimentos de ondas e timbre. Desta forma, a proposta da sequência didática apresenta um conjunto de vídeos. O primeiro auxilia a percepção da frequência, abordando sons graves e agudos, servindo de organizador prévio, em outro vídeo é abordada a forma da onda sonora no tubo de Kundts que mobiliza os subsunçores do processo, e o último vídeo mostra a influência do estado de movimento da fonte e do observador na percepção da frequência realizando uma reconciliação integrativa. Por fim, a sequência didática se encerra utilizando uma simulação do efeito Doppler no software Modellus. 


\section{Vídeo como organizador prévio e mobilizador de diferenciação progressiva}

Ao iniciarmos o assunto os discentes possuem os subsunçores apropriados pois o conceito de frequência já foi abordado anteriormente, logo a associação com frequêencia sonora pode ser realizada por meio de um vídeo demonstrativo que faz o papel de organizador prévio. A escolha novamente foi utilizar um vídeo do site www.youtube.com em virtude da facilidade de acesso, entre as variadas possibilidades o vídeo do endereço https://www.youtube.com/watch?v=HkzVxwghiik se destaca por mostrar a vibração associada a frequência sonora. Isso permite a introdução do conceito de graves e agudos (figura 3.15).

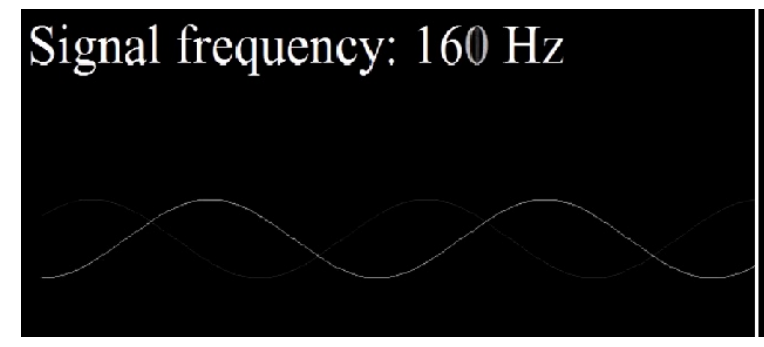

\section{Signal frequency: $560 \mathrm{~Hz}$}

Figura 3.15: Variação de frequência sonora.

Posteriormente se apresenta um segundo vídeo também do site www.youtube.com cujo endereço é https://www.youtube.com/watch?v=qUiB_zd9M0k. Nessa visualização é possível associar diretamente a frequência ao modo de vibração de uma onda sonora (figura 3.16) realizando uma diferenciação progressiva pela aplicação de perguntas aos discentes a exemplo das contidas no apêndice A.

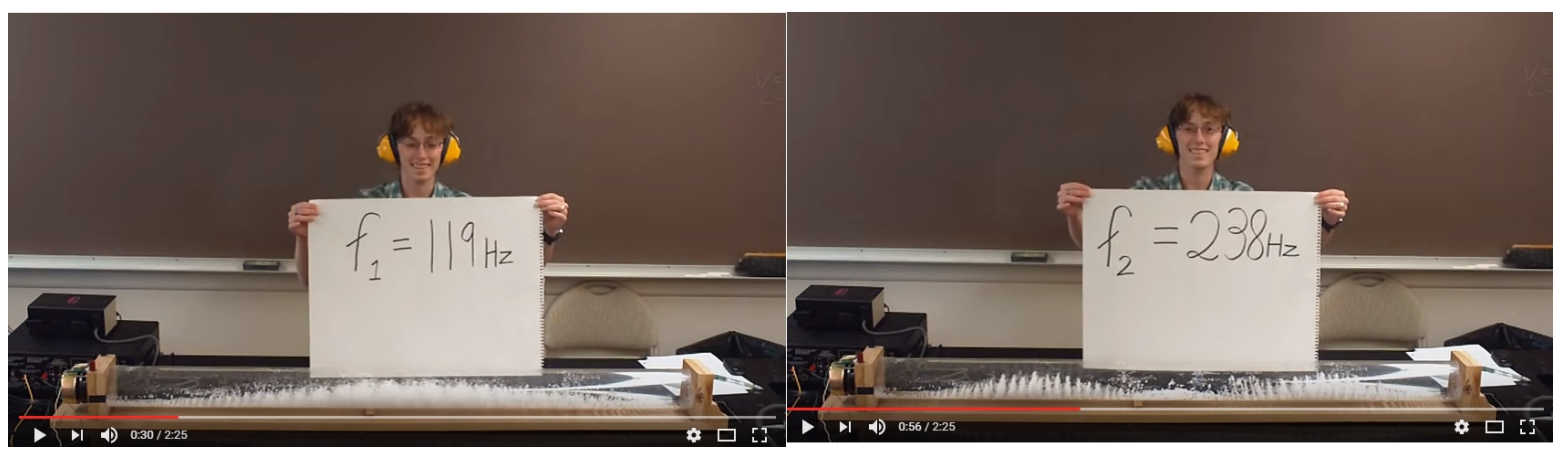

Figura 3.16: Modo de vibração da onda em função da frequência. 


\section{O Efeito Doppler e sua abordagem como uma reconciliação integrativa}

Analisar as influências do estado de movimento de fonte e do ouvinte em relação as alterações verificadas na frequência proporciona uma das descrições mais ricas e belas da Física. Nessa construção realizamos uma série de recombinação de conceitos previamente existentes na estrutura cognitiva do estudante e esta ação proporciona de maneira manifesta uma reconciliação integrativa. A filmagem produzida pelos professores Amadeu, Giovanninni e Pedro aborda de maneira qualitativa o Efeito Doppler. Eles desenvolvem o vídeo realizando todas as configurações possíveis dos estados de movimento e mudança na percepção da frequência de maneira qualitativa. O vídeo está hospedado no site www.youtube.com e pode ser assistido pelo link https://www.youtube.com/watch?v=8XcJf4rOefE (figura 3.17).

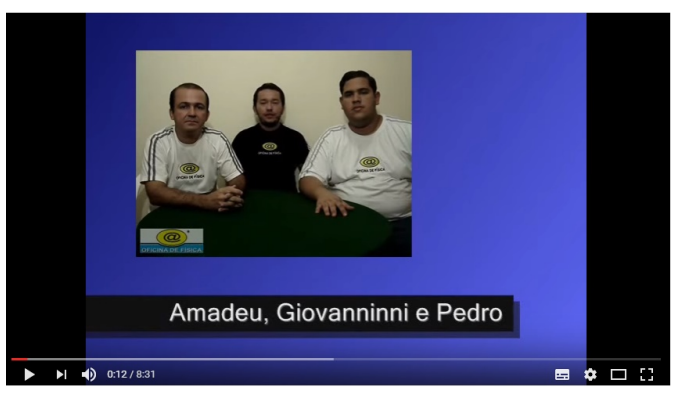

Figura 3.17: Apresentação do Efeito Doppler pelo Mago da Física.

Após essa visualização o professor realiza a discussão quantitativa do Efeito Doppler com apoio de uma simulação construída no software Modellus que pode ser obtida no site http://fisicanalixa.blogspot.com.br/ (figura 3.18)

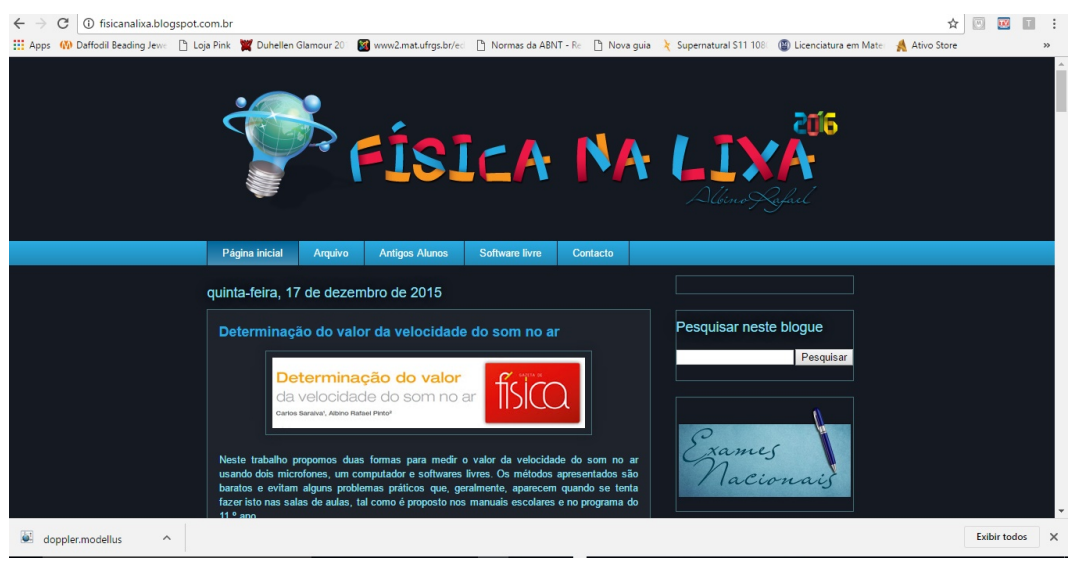

Figura 3.18: Site de divulgação de simulações no software Modellus. 
Nessa home page estão disponíveis várias simulações produzidas por diferentes autores a respeito de variados objetos do conhecimento da Física. A proposta para encerrar a sequência didática é utilização da simulação obtida pelo endereço http://fisicanalixa.blogspot.com.br/2010/09/efeito-doppler.html (3.19).

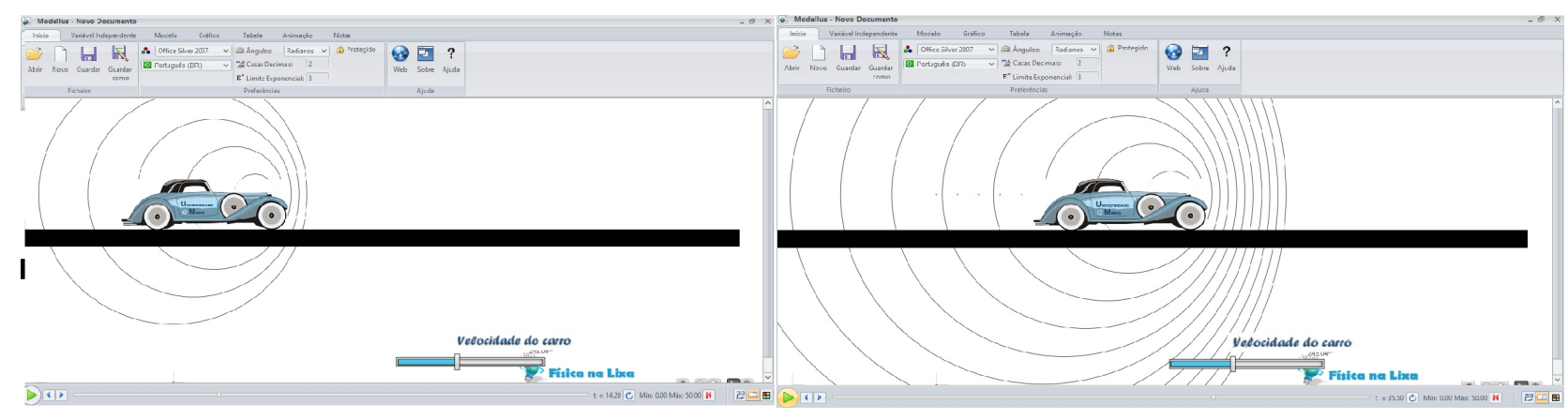

Figura 3.19: Configuração das frentes de onda no Efeito Doppler.

Nessa simulação se pode visualizar a dispersão das frentes no sentido contrário ao deslocamento de móvel, indicando diminuição na frequência (som grave) e a concentração de frentes de onda no sentido de deslocamento do móvel, indicando aumento na frequência (som agudo). 
Capítulo 4

\section{Relato da experiência didática e análises}

Realizaremos neste capítulo o relato da experiência didática vivenciada pela aplicação do produto educacional descrito no capítulo anterior. Inicialmente descreveremos o local, as condições e o período letivo de aplicação das sequências didáticas. Depois apresentaremos os dados obtidos da aplicação do produto educacional e sua análise. Por fim, apresentamos uma validação incipiente do produto educacional.

\subsection{O ambiente escolar e a aplicação das sequências didáticas}

O colégio onde foram aplicadas as sequências didáticas é a maior unidade do Sistema Colégio Militar do Brasil, integra uma rede de ensino diferenciada em virtude de ser um estabelecimento de ensino federal e estar subordinado diretamente ao Ministério da Defesa e não ao Ministério da Educação e Cultura. O Colégio Militar de Brasília localizado na Asa Norte, quadras 902/904, apresenta em média um efetivo de 2800 alunos. Funciona em dois turnos, sendo o ensino fundamental a tarde e o ensino médio pela manhã. O corpo docente da disciplina de Física é constituído por 14 professores cuja titulação predominante é o doutorado. Todavia, esses profissionais não são pesquisadores da área de ensino e nem na área de ensino de Física. O produto educacional foi aplicado no segundo ano do ensino médio o qual é constituído por 15 turmas cada uma com 32 alunos em média. A equipe de Física desse ano escolar é 
formada por quatro professores, dois doutores e dois mestres.

A aplicação das sequências didáticas ocorreram em três turmas do segundo ano cuja regência era do próprio professor que elaborou o produto educacional. Tais turmas X, Y e Z apresentavam em média 32 alunos cujas habilidades de aprendizado são heterogêneas. O período de aplicação se estendeu por momentos do primeiro trimestre do calendário letivo (figura 4.1)

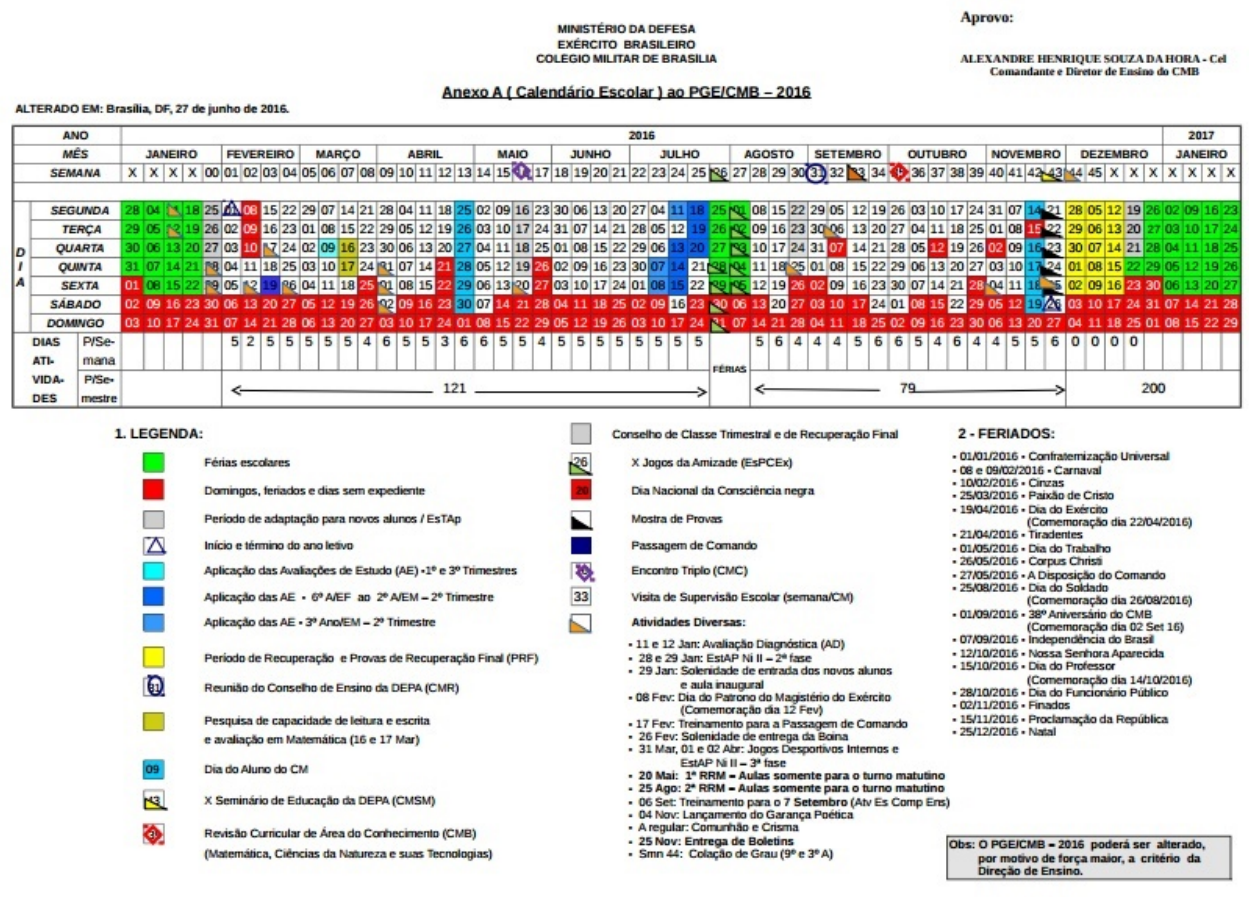

Figura 4.1: Calendário do Colégio Militar de Brasília.

\section{A compreensão do MHS por meio de uma sequência didática}

A primeira sequência didática foi aplicada nas semanas 01 a 03 e utilizou 07 aulas de $45 \mathrm{~min}$, ocorreu um bom acompanhamento dos discentes apesar do objeto de conhecimento apresentar um nível de dificuldade considerável. A falta de suporte do livro didático adotado causou um incômodo nos alunos os quais estão habituados a utilizar esse instrumento como única fonte de estudo. Isso aconteceu pois não estava disponível, como um dos assuntos abordados no livro, o tema Movimento Harmônico Simples. Assim, algo que poderia ser bom, o trabalho independente de um livro conservador, não foi compreendido pelos alunos os quais ficam numa posição 
confortável na formatação de uma aula tradicional que os considera meros recipientes de técnicas de resolução de exercícios.

A condução da abordagem apresentou a seguinte sequência de eventos:

A - Exposição do vídeo (figura 3.2) sobre o funcionamento de uma máquina a vapor.

B - Realização de sondagem por meio das seguintes perguntas a turma:

1 Qual(is) o(s) tipo(s) de movimento(s) observado(s) na máquina a vapor?
(A) Movimento Retilíneo.
(B) Movimento Circular.
(C) Movimento Circular Uniforme.
(D) Movimento Harmônico Simples.
(E) Não sei informar.

A resposta dos alunos foi sintetizada nos gráficos a baixo e analisada em seguida.

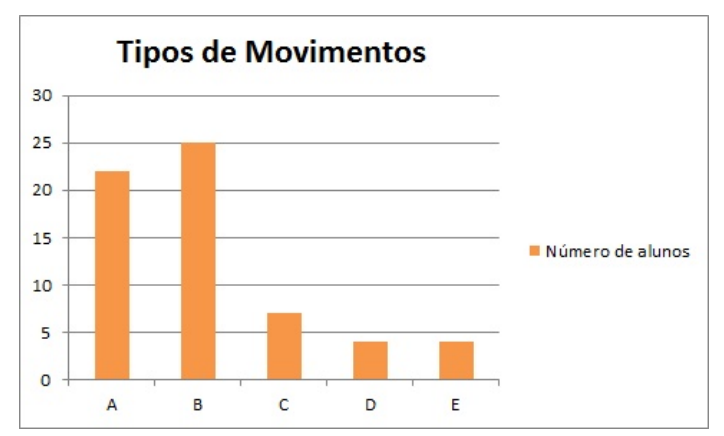

(a) Turma X

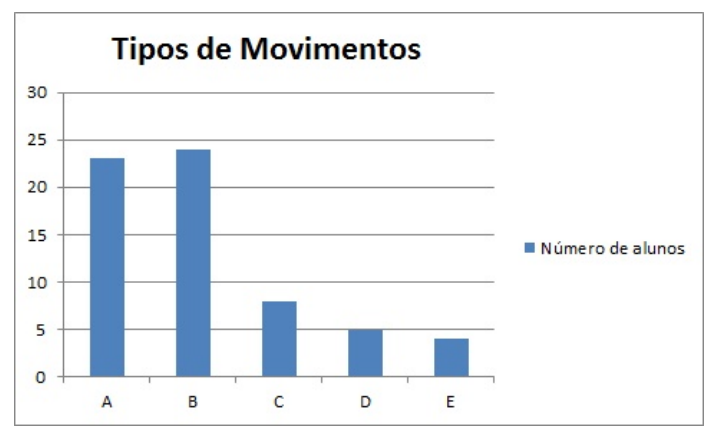

(b) Turma Y

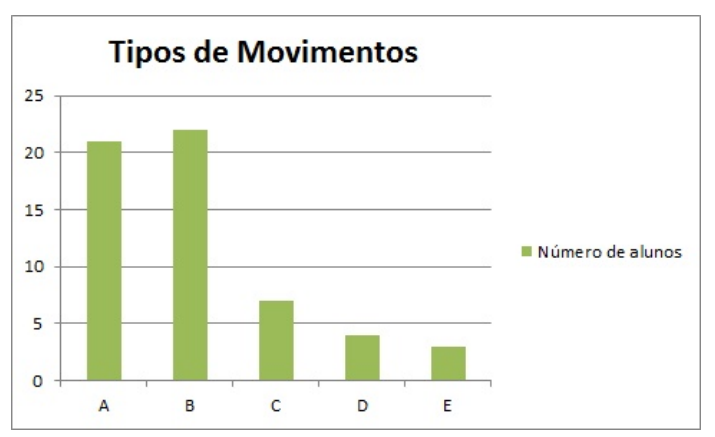

(c) Turma Z

Figura 4.2: Identificação dos tipos de movimentos das partes da máquina a vapor. 
Os gráficos revelam que a resposta das turmas $\mathrm{X}, \mathrm{Y}$ e $\mathrm{Z}$ ao observado no vídeo são semelhantes, o que era de se esperar, pois a distribuição heterogênea de alunos tende a fornecer resultados de amostras que sejam congruentes. Assim, pode-se perceber que boa parte dos alunos consegue verificar o movimento circular da roda e não classifica como uniforme. Talvez esse resultado esteja influenciado pelo início e término do funcionamento da máquina quando existe uma aceleração no sistema. Outra observação se faz pela identificação do movimento do pistão como retilíneo e não como harmônico simples por parte considerável da turma. No entanto, isso já era esperado em virtude de não possuem em sua estrutura cognitiva o subsunçor para reconhecer o fenômeno oscilatório como harmônico simples.

2 Existe alguma relação entre os movimentos das partes da máquina a vapor?
(A) Não.
(B) Sim.
(C) Não sei informar.

Novamente sintetizamos as respostas por gráficos e em seguida apresentamos a análise dos resultados.

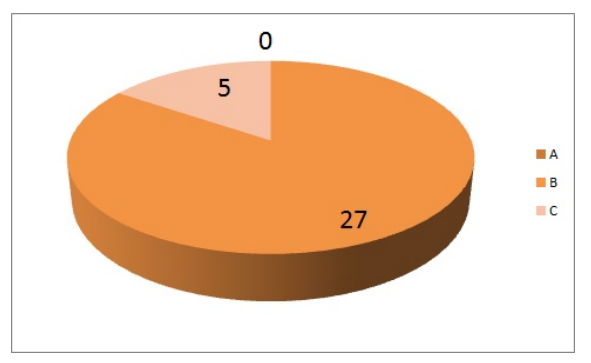

(a) Turma X

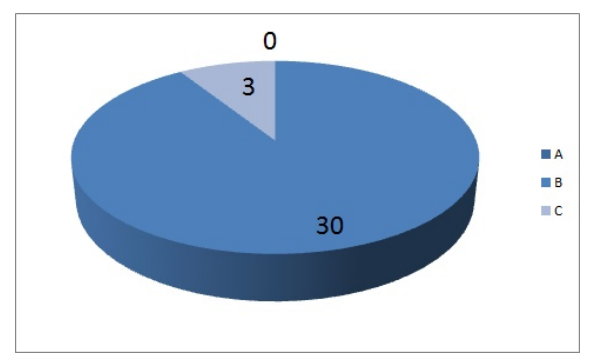

(b) Turma Y

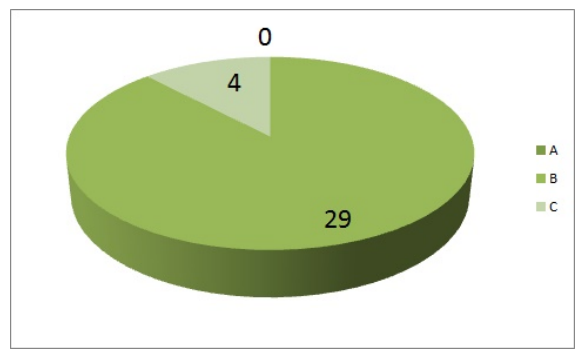

(c) Turma Z

Figura 4.3: Percepções da relação entre o movimento das partes da máquina a vapor. 
Confirmando o observado anteriormente os gráficos revelam amostras congruentes. Além disso, pode-se perceber que em todas as turmas os alunos foram capazes de notar uma relação entre o movimento da roda com o pistão e poucos não quiseram apresentar suas opiniões.

3 A descrição desse(s) movimento(s) pode(m) ser realizada(s) por qual(is) função(ões) matemática(s)?
(A) Função do $1^{o}$ grau.
(B) Função do $2^{o}$ grau.
(C) Funções trigonométricas.
(D) Não sei informar.

Os gráficos apresentados abaixo sintetizam as respostas e em seguida é realizada a análise dos resultados.

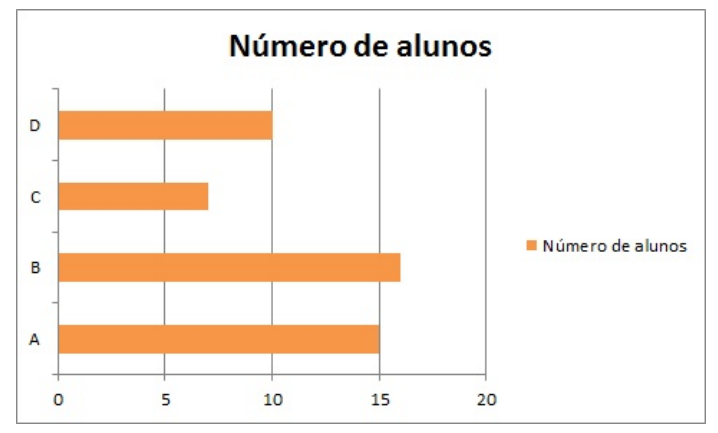

(a) Turma X

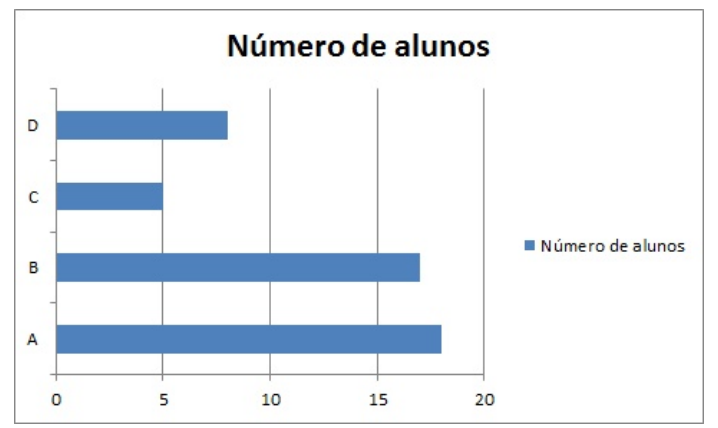

(b) Turma Y

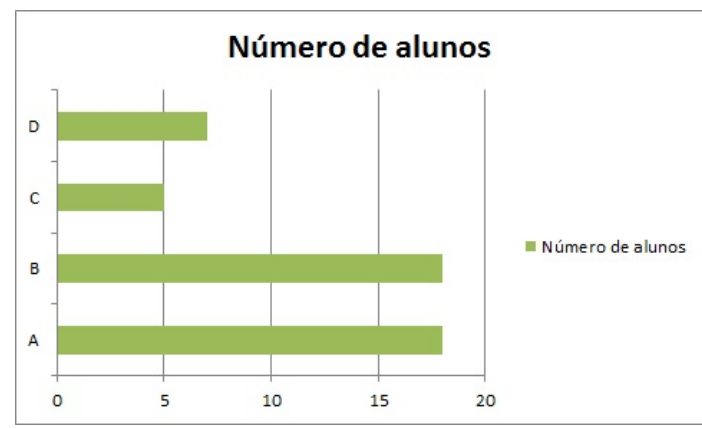

(c) Turma Z

Figura 4.4: Respostas identificando as funções matemáticas.

O padrão de respostas apresentou-se novamente semelhante nas três turmas. Isso fornece indícios de que as turmas realmente podem ser consideradas heterogêneas, 
corroborando o que é um princípio pedagógico de organização de ensino do Sistema Colégio Militar. Além disso, ficou evidente o pouco conhecimento de Funções trigonométricas para descrição de movimentos. Quando os discentes foram indagados pelo professor em sala de aula sobre o porquê de utilizarem Função do $1^{\circ}$ grau e Função do $2^{o}$ grau como alternativas relataram que o movimento da roda é uniforme então a função deve ser do primeiro grau e como o pistão tem velocidade variável deveria ser uma função do segundo grau.

C Utilização do software Modellus X na compreensão do Movimento Hârmonico Simples.

Poucos alunos conheciam o Movimento Hârmonico Simples conforme o diagnóstico apontou. Assim, após a intervenção do professor voltando ao vídeo e caracterizando tal movimento foi utilizada a simulação no software Modellus X (figura 3.3) a fim de reproduzir os movimentos da roda e do pistão. Para tal foi salientada a necessidade de se utilizar funções trigonométricas, onde seus elementos: amplitude, frequência e velocidade angular foram explicados e caracterizados. Assim, ficou verificado que a projeção do movimento circular em um dos eixos ortogonais descreveria adequadamente um movimento oscilatório.

D - Utilização do software Newton na identificação de movimentos harmônicos no sistema massa-mola e no pêndulo.

Procedendo com os debates sobre o Movimento Hârmonico Simples o tema abordou a dinâmica desse objeto do conhecimento e vários contextos em que se manifesta. Foram discutidos exemplos e resolvidos alguns exercícios contextualizados como exemplo. A extensão desse movimento a outros objetos oscilantes se fez pela utilização do software Newton (figura 3.6), o qual mostra bem o compasso entre um Movimento Circular, o Sistema Massa-Mola e o Pêndulo. Sendo posteriormente possível deduzir o período do sistema massa - mola

$$
T=2 \pi \sqrt{\frac{m}{K}}
$$

onde m é a massa que oscila e K a constante elástica da mola; e o período do pêndulo

$$
T=2 \pi \sqrt{\frac{l}{g}}
$$


onde 1 é o comprimento do fio e g o módulo da aceleração da gravidade. Nessa abordagem surgiu uma oportunidade interessante de se discutir o filme interestelar quando se destaca a dependência do tempo com a gravidade, a qual serviu de estímulo para a prática de laboratório prevista.

E - A medida da aceleração da gravidade por meio do período de um pêndulo.

Ao fim da sequência didática foi aplicada uma prática de laboratório bem simples onde os discentes utilizaram massas de metal, linha e suporte para montar pêndulos de diferentes tamanhos e massas. Em seguida, manuseando um cronômetro e régua lançaram mão da expressão 4.2 para medir o valor da aceleração da gravidade em pelo menos dois pêndulos distintos. O roteiro da prática se encontra no apêndice B e os resultados obtidos pelos alunos, $\mathrm{g} \approx 10$ independentemente das modificações nos parâmetros do pêndulo, indicando um bom aproveitamento da atividade.

\section{Sequência didática para compreensão do Fenômeno de Interferência de Ondas.}

A aplicação da segunda sequência didática aconteceu nas semanas 06 e 07 e utilizou 05 aulas de $45 \mathrm{~min}$, foi inserida num momento em que era desenvolvida a abordagem de ondulatória de forma tradicional com auxílio restrito do quadro negro e livro didático. Assim, foi realizada uma mudança na metodologia de ensino, ou seja, passaram a acontecer aulas colaborativas por meio de vídeos e softwares, a prática do docente tornou-se interativa. A mudança de método de ensino permitiu uma ativação dos discentes que participaram efetivamente da aula indicando assim uma predisposição maior para aula.

A condução da abordagem apresentou a seguinte sequência de eventos:

A - Exposição do vídeo (figura 3.8) sobre a propagação de ondas na superfície de um lago.

B - Realização de sondagem por meio das seguintes perguntas a turma:

1 Qual(is) o(s) tipo(s) de onda(s) observado(s) na superfície do lago?

(A) Longitudinais em uma dimensão. 
(B) Transversais em uma dimensão.

(C) Longitudinais em duas dimensões.

(D) Transversais em duas dimensão.

(E) Não sei informar.

A resposta dos alunos foi sintetizada nos gráficos a baixo e analisada em seguida.

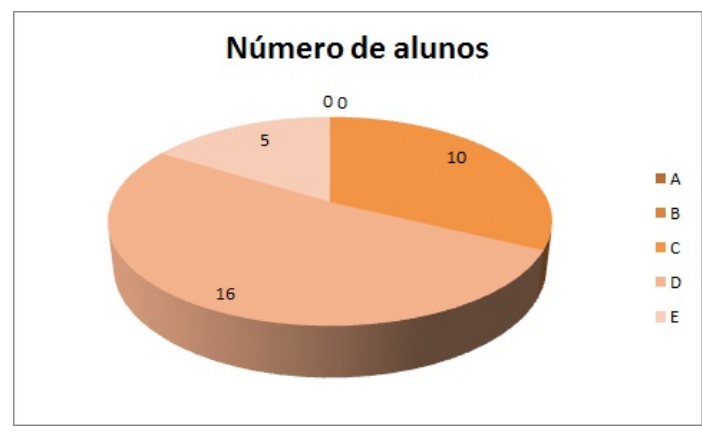

(a) Turma X

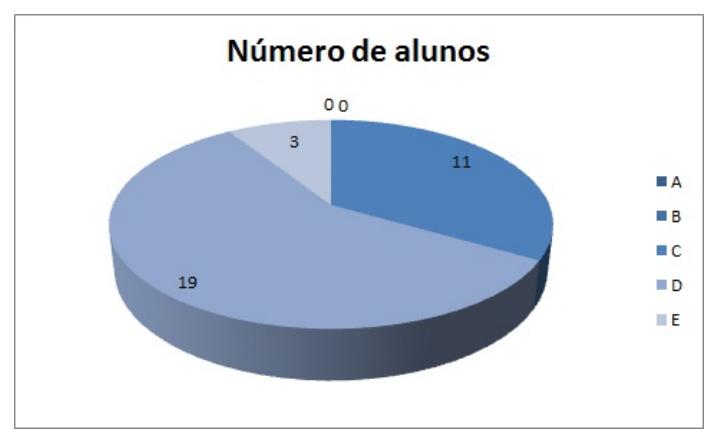

(b) Turma Y

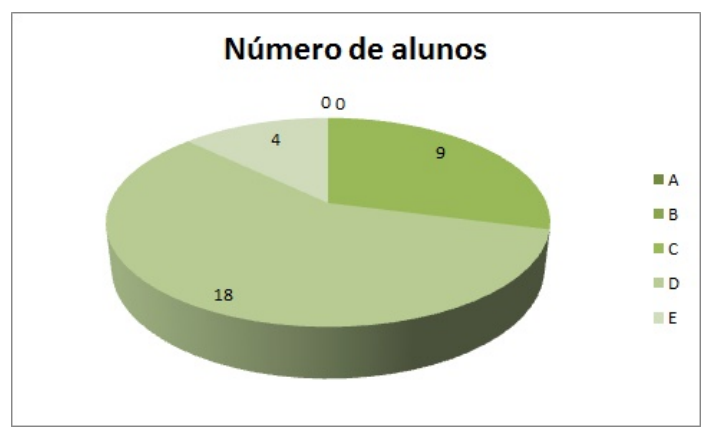

(c) Turma Z

Figura 4.5: Respostas sobre a identificação das ondas na superfície do lago.

Observam-se padrões de respostas semelhantes entre as turmas o que também foi característico na sondagem da sequência didática anterior. Também pode-se perceber o reconhecimento predominante de ondas bidimensinais no fenômeno observado no vídeo, isso mostra a presença de conhecimento prévios apropriados para a ação de subsunçores. No entanto é constatado uma dificuldade de diferenciar ondas longitudinais de transversais na superfície d'agua.

2 Qual(is) o(s) elemento(s) da onda que pode(m) ser nitidamente observado(s)?
(A) Comprimento. 
(B) Amplitude.

(C) Frequência.

(D) Não sei informar.

Novamente sintetizamos as respostas por gráficos e em seguida apresentamos a análise dos resultados.

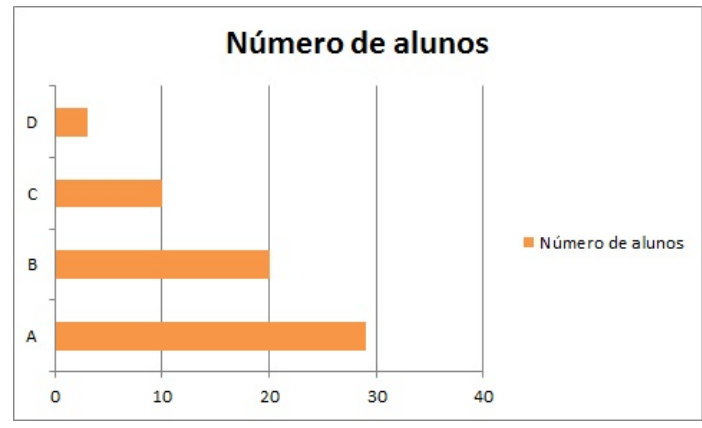

(a) Turma X

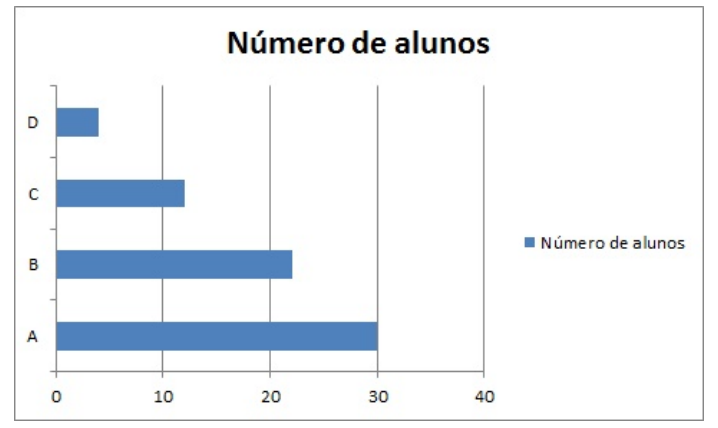

(b) Turma Y

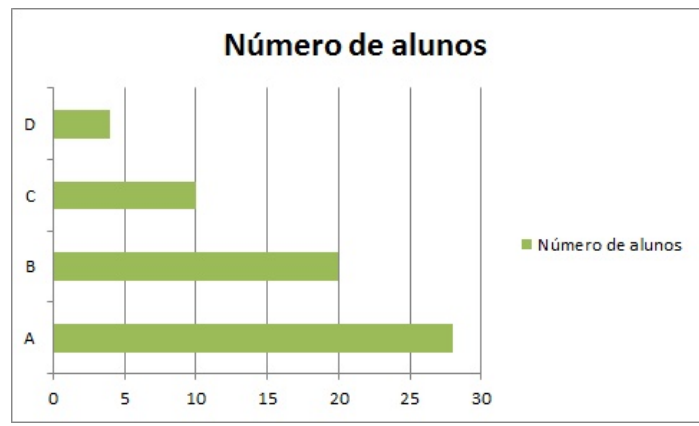

(c) Turma Z

Figura 4.6: Respostas reconhecendo os elementos de ondas.

Por meio dos gráficos podemos inferir que os alunos conseguem perceber claramente a comprimento da onda nas pertubações realizadas na superfície d'agua. Porém não ficou evidente a frequência de tais ondas, provavelmente isso decorreu de não se acompanhar a passagem de uma frente de onda por um ponto fixo da superfície. Um número considerável de estudantes não conseguiu notar a amplitude da onda e poucos não expressaram opinião. No decurso da abordagem do conteúdo foi esclarecido o conceito de frequência e foi destacado que a percepção da amplitude era meramente qualitativa.

3 Qual(is) o(s) fenômeno(s) observado(s) quando é introduzida a segunda fonte? 

(A) Batimento.
(B) Ondas Estacionárias.
(C) Interferência.
(D) Não sei informar.

A resposta dos alunos foi sintetizada nos gráficos a baixo e analisada em seguida.

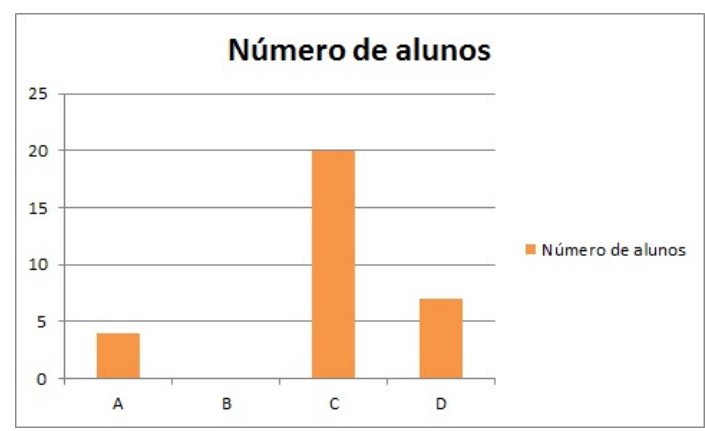

(a) Turma $\mathrm{X}$

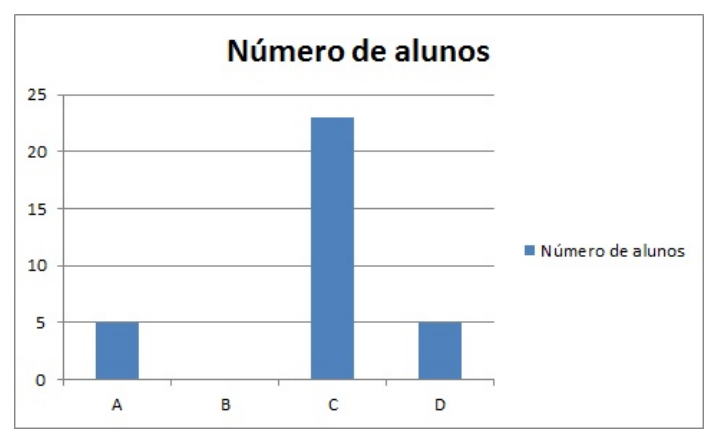

(b) Turma Y

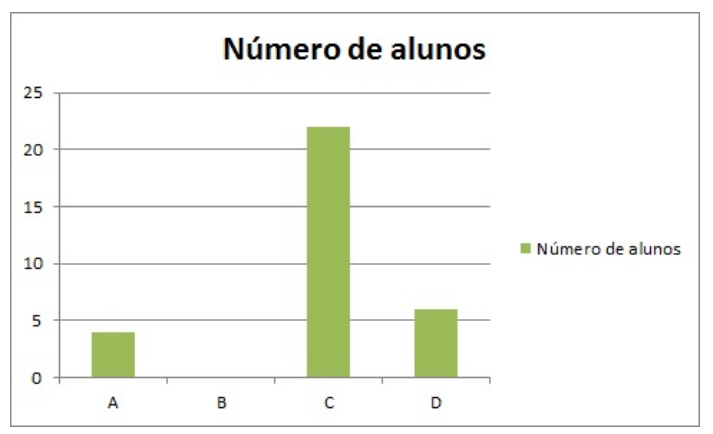

(c) Turma Z

Figura 4.7: Respostas identificando o fenômeno de superposição.

Os gráficos demonstram que boa parte dos alunos reconhecem o efeito de interferência nas ondas produzidas por duas fontes na superfície do lago. Provavelmente esse resultado decorre do conhecimento prévio de interferência em ondas unidimensionais. Quando foram indagados a respeito de não observarem ondas estacionárias argumentaram que as frentes de onda se propagavam e isso não ocorria em ondas estacionárias, evidenciando aprendizagem sobre esse conceito. Sobre a visualização de batimentos alguns disseram que fizeram confusão com a nomenclatura.

C Utilização do software Ondas 2.0 na compreensão da Interferência. 
Por meio do software Ondas 2.0 (figura 3.10) abordamos o módulo de ondas em uma dimensão explorando sua propagação, superposição formando batimentos e ondas estacionárias. De forma que a diferenciação progressiva tornou-se efetiva e promoveu a formação de novos subsunçores. Além disso construímos diversos padrões de interferência variando os parâmetros do programa. A operação desse software é mais simplificada comparada a do Modellus X o que proporcionou um interesse maior dos alunos na operação do programa.

D Simulação no PhET para integrar ondas na superfície de um lago com ondas sonoras.

O site do PhET disponibiliza módulos diferenciados para abordagem de distintos objetos de conhecimento da Física. Ao utilizarmos o módulo de interferência em ondas na superfície d'agua conseguimos rever os elementos construídos no software Ondas. Entretanto, a intenção de se trabalhar com o PhET foi contrastar esse fenômeno com o de interferência sonora. Assim, comparamos todos os parâmetros de ambos os módulos destacando suas funções de forma que ficou claro a semelhança dos fenômenos seja na água ou no ar. Uma atenção especial foi conseguida quando a figura do ouvinte era colocada em uma região de interferência destrutiva e não se ouvia som emitido pelo programa (figura 3.14). Ao fim dessa atividade percebemos a consolidação de uma reconciliação integrativa entre os conceitos.

\section{A compreensão da Frequência e Efeito Doppler utilizando uma sequências didática}

A última sequência didática foi aplicada nas semanas 11 e 12 e utilizou 04 aulas de $45 \mathrm{~min}$, encerrou os assuntos do primeiro trimestre de forma que muitos elementos do objeto do conhecimento já estavam interiorizados pelos discentes. Um aspecto importante se deu por novamente ocorrer uma mudança na metodologia de ensino caracterizada pela alternância entre aulas ativas e aulas expositivas. O estudo de acústica iniciou de maneira tradicional com auxilio exclusivo do quadro negro e livro didático, o que se modificou quando abordamos as caracteristicas fisiológicas do som e o Efeito Doppler. A mudança de método de ensino permitiu, novamente, uma ativação dos discentes os quais passaram a contribuir efetivamente com a aula indicando assim uma melhor predisposição para aprendizagem.

A condução da abordagem apresentou a seguinte sequência de eventos: 
A - Apresentação dos vídeos das figuras 3.15 e 3.16 sobre frequência e modos de vibração a fim de realizar diferenciação integrativa.

B - Realização de sondagem por meio das seguintes perguntas a turma:

1 Sobre frequência podemos compreender que são?

(A) Pertubações espaciais da onda.

(B) Pertubações temporais da onda.

(C) Agudas quando o som é fino.

(D) Graves quando o som é fino.

(E) Algo que não sei informar.

A resposta dos alunos foi sintetizada nos gráficos a baixo e analisada em seguida.

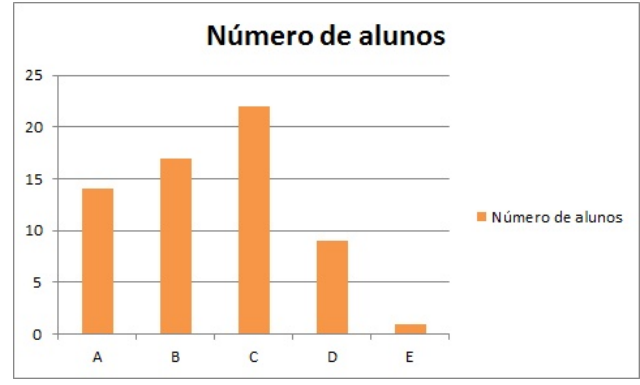

(a) Turma X

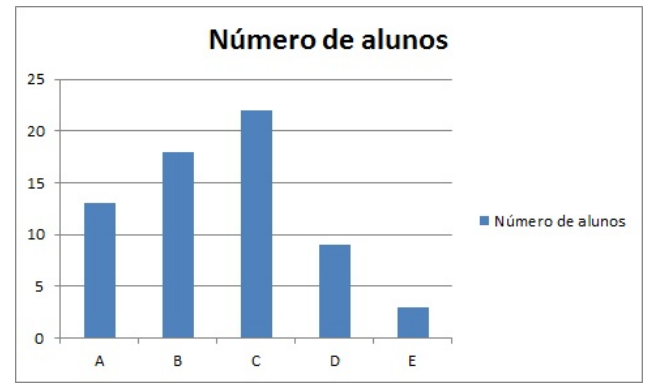

(b) Turma Y

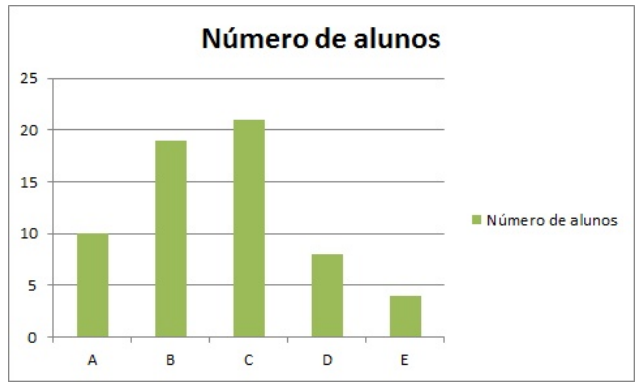

(c) Turma Z

Figura 4.8: Respostas caracterizando frequência.

Os padrões de respostas são parecidos entre as turmas, exceto pelo número de alunos que não reconheceu o significado de frequência nas turmas $\mathrm{Y}$ e Z o que proporcionou um debate para recaptulação dos conceitos nessas turmas. Outro observação ocorreu com o conceito de frequência como perturbação espacial ou temporal. 
Os alunos argumentaram que expor os modos de vibração antes da pergunta causou uma confusão sobre o conceito o qual foi devidamente esclarecido pelo professor. Por fim, a ideia de som fino e som grosso foi ajustado ao conceito de agudo e grave utilizando o exemplo da voz feminina e da masculina. Mesmo com essas alterações conceituais notamos que a aplicação dos vídeos serviu para consolidar e organizar os conhecimentos prévios dos alunos além de proporcionar diferenciação integrativa.

2 Ainda sobre frequência podemos dizer que depende
(A) da fonte de emissão da onda.
(B) do meio que a onda se propaga.
(C) da fonte de emissão da onda e do meio pelo qual se propaga.
(D) de algo que não sei informar.

Novamente sintetizamos as respostas por gráficos e em seguida apresentamos a análise dos resultados.

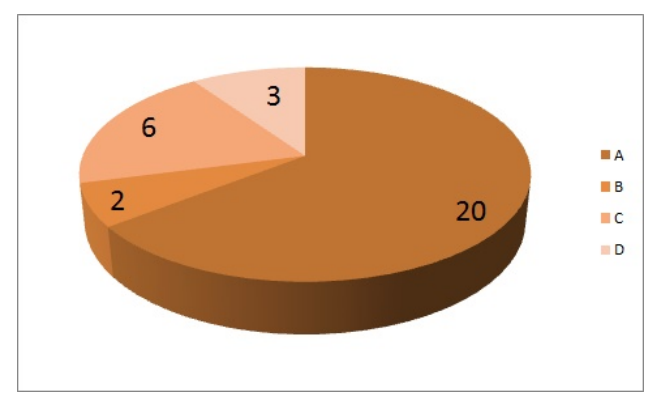

(a) Turma X

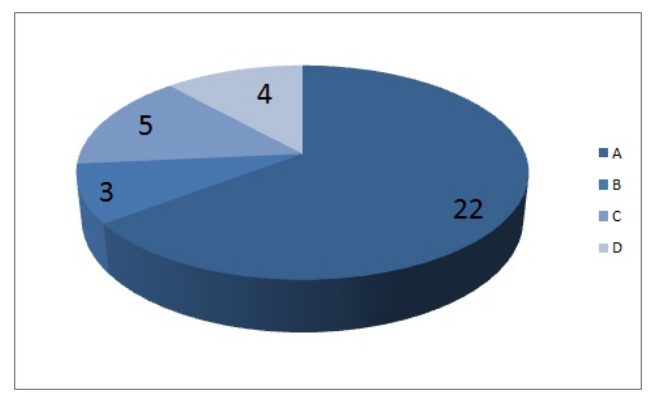

(b) Turma Y

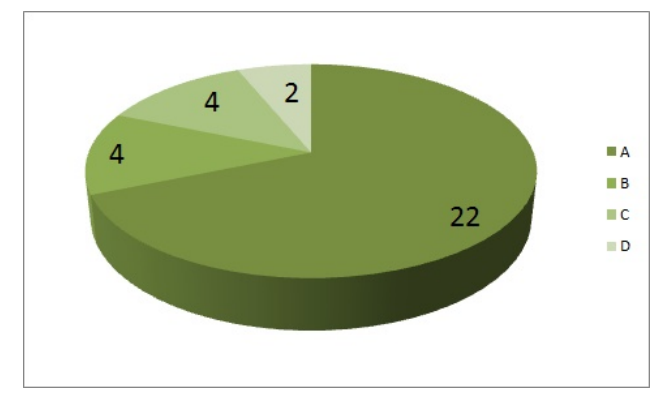

(c) Turma Z

Figura 4.9: Respostas sobre frequência.

Por meio dos gráficos podemos inferir que os alunos conseguem expressar que a frequência depende da fonte de ondas, isso era esperado pois na abordagem da sequência didática anterior tal conceito já tinha sido explorado e discutido esgotadamente. 
Todavia, alguns alunos atribuíram à frequência alguma dependência do meio o que evidenciou alguma confusão com o conceito de velocidade de propagação. Esse fato foi abordado e retificado pelo professor e acabou sendo um instrumento apropriado para realizar a organização previa dos conhecimentos. Poucos alunos não manifestaram respostas e quando aconteceu provavelmente decorreu de motivos alheios a aprendizagem.

3 Quando a fonte de ondas esta em movimento isso afeta a frequência percebida por meio

(A) da velocidade da onda.

(B) do comprimento da onda.

(C) a própria frequência emitida.

(D) de algo que não sei informar.

A resposta dos alunos foi sintetizada nos gráficos a baixo e analisada em seguida.

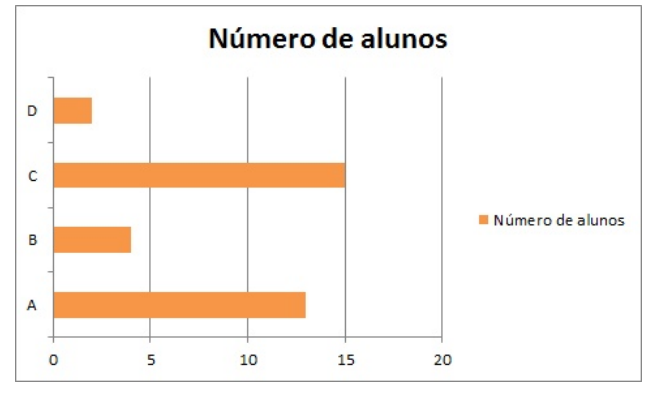

(a) Turma X

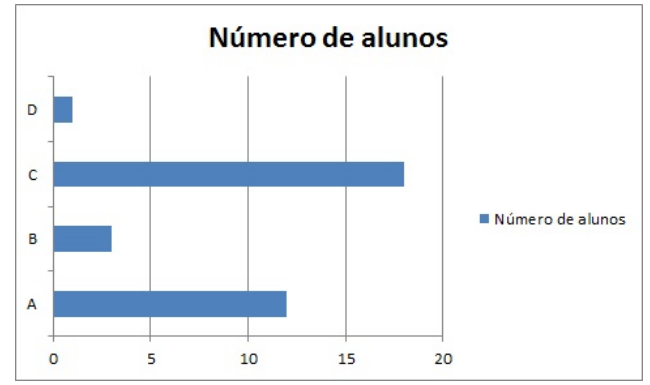

(b) Turma Y

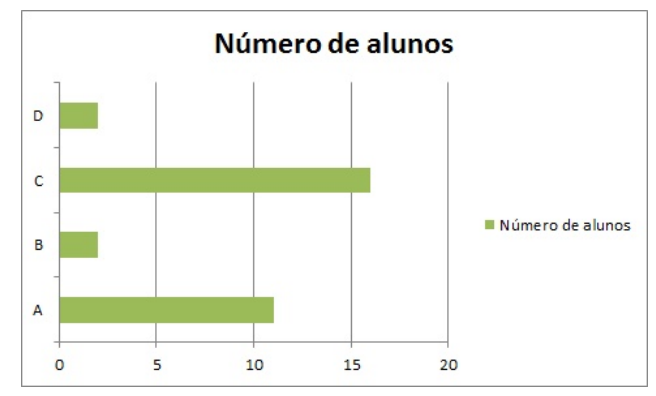

(c) Turma Z

Figura 4.10: Respostas sobre a influência do estado de movimento da fonte na frequência.

Utilizando os gráficos podemos constatar que o Efeito Doppler é conhecido pela maioria dos alunos e atribuem sua existência a mudança na frequência. Outra fração 
significativa relacionava o efeito a mudança na velocidade da onda, após um debate com os alunos se pode perceber que essa percepção se devia a uma provável soma de velocidades da fonte e da onda. Tal pensamento é comum mesmo em professores que não percebem uma assimetria no Efeito Doppler. A situação da fonte em movimento gera ondas em posições distintas diferentemente de quando o ouvinte se movimenta e a fonte está parada.

C Utilização do Vídeo produzido pelo Mago da Física no detalhamento do Efeito Doppler e proporcionando reconciliação integrativa.

O vídeo proposto (figura 3.17) possibilita que o aluno experiencie a situação mesmo que de forma virtual e aborda de forma qualitativa o efeito Doppler fazendo sua descrição de forma detalhada e apropriada. Sua produção é antiga e pode ser refeita utilizando detectores de frequência para uma análise quantitativa do Efeito Doppler. Em sala de aula os alunos demonstraram bastante interesse em assistir o o vídeo e propuseram sua reprodução, todavia isso não foi possível em virtude de estar fora do planejamento das atividades letivas do trimestre e do tempo de planejamento que seria demandado. A compreensão da influência do estado de movimento da fonte e observador foi bem sucedida o que proporcionou a reconciliação integrativa dos conceitos

D Manipulação do Software Modellus X na compreensão do Efeito Doppler.

O módulo do Efeito Doppler no software Modellus X (figura 3.19) aborda exclusivamente a situação da fonte em movimento e ilustra corretamente a mudança na frequência ouvida pelo observador em repouso atrás e a frente da fonte. Os alunos manifestaram grande entusiasmo com a compreensão do efeito. Houve tentativa de construção de um módulo mais completo por parte do professor, porém a falta de habilidade com o software foi um fator impeditivo.

Após a utilização das sequências didáticas foi aplicado um questionário ( apêndice C) a fim de se perceber de maneira incipiente o resultado da metodologia adotada para as aulas. 


\subsection{Percepção discente das aplicações das sequências didáticas}

A efetividade das sequências didáticas foi verificada por meio de um único questionário aplicado a uma amostra de 11 alunos de cada turma. Em virtude dos diagnósticos obtidos nas sequências didáticas, apresentados no capítulo anterior, indicar uma percepção semelhante entre os discentes a análise desses questionários foi realizada sem distinção entre as turmas. Essa forma de validação do produto é apenas qualitativa e não fornece subsídios para aferir se as sequências didáticas foram Unidades de Ensino Potencialmente Significativas. Desta forma, no desenvolvimento do trabalho foi adotado o conceito de sequências didáticas próximas de Unidades de Ensino Potencialmente Significativas. O motivo de utlizar uma avaliação qualitativa decorre da determinação feita pela supervisão escolar do Colégio Militar de Brasília para suas equipes trabalharem de forma homogênea, o que impede a aplicação de avaliação diferenciada por parte do autor do trabalho.

\section{Verificação da aceitação e efetividade das sequências didáticas}

Após o cabeçalho do questionário foi exposto o seguinte paragrafo de apresentação:

O objetivo deste questionário é coletar as opiniões, construídas com segurança e reflexão, dos discente sobre diferentes aspectos desta disciplina, sua condução dada pelas sequências didáticas ativas estruturadas em alguns assuntos abordados, bem como saber como o aluno se autoavalia. Os dados fornecerão ao professor condições de refletir sobre sua produtividade com relação ao processo de ensino-aprendizagem. Portanto, a seriedade nas respostas às questões é de suma importância. Para responder às questões, utilize a seguinte escala de valores: 1 - Não; 2 - Sim, pouco(a); 3 Sim, suficiente; 4 - Sim, satisfatoriamente; 5 - Sim, plenamente.

As peguntas foram divididas em três blocos, o primeiro tratando da sequência didática, o segundo sobre os recursos utilizados e o terceiro sobre a postura do discente.

1 O objeto do Conhecimento - Sequência Didática

A) Conhecia o objeto de conhecimento exposto? 
B) A sequência didática foi previamente apresentada pelo professor?

C) A organização realizada facilitou a compreensão?

D) Percebeu a importância do assunto na sua formação?

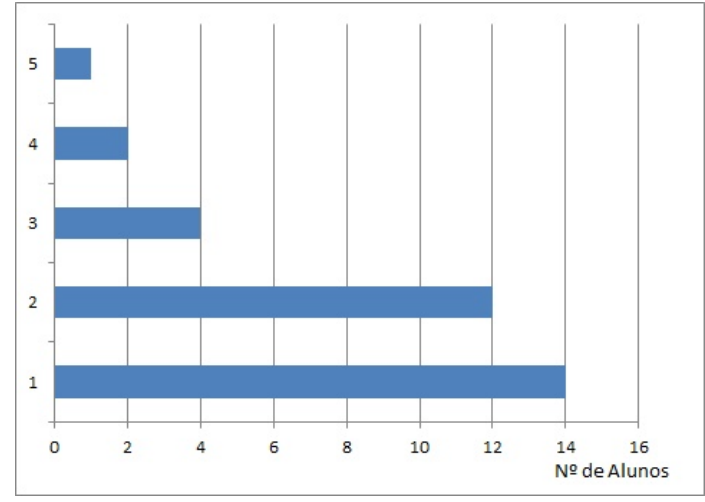

(a) Item A

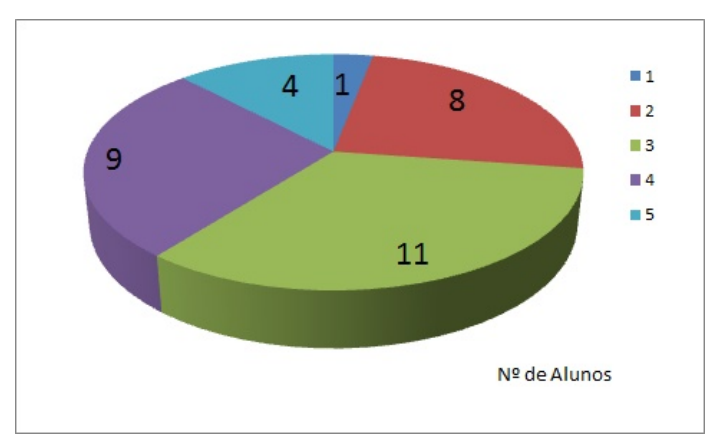

(c) Item C

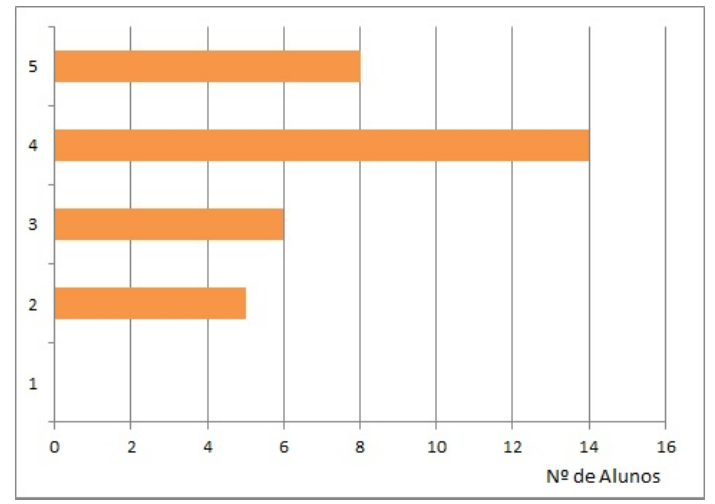

(b) Item B

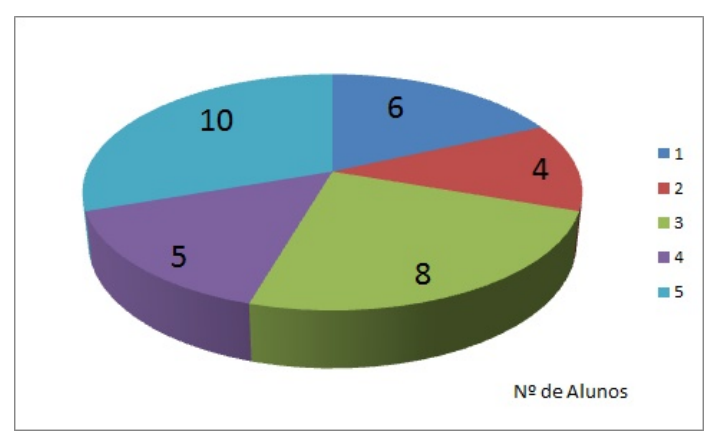

(d) Item D

Figura 4.11: Perguntas sobre o objeto do conhecimento - Sequência Didática

Análise desses gráficos revelam as seguintes observações:

- o objeto do conhecimento não era familiar aos estudantes de forma suficientemente relevante;

- o professor sumarizou o sequência didática utilizada;

- a compreensão foi facilitada pela organização; e

- a maior parte dos estudantes reconheceu a importância do assunto na sua formação. 
2 Recurso Audiovisual

A) Conseguiu compreender a(s) situação(ões) abordada(s)?

B) Participou ativamente no debate sobre o fenômeno observado no recurso audiovisual?

C) Percebeu a relação da situação(ões) exposta(s) com o objeto do conhecimento?

D) O recurso audiovisual facilitou o esforço de aprendizagem?

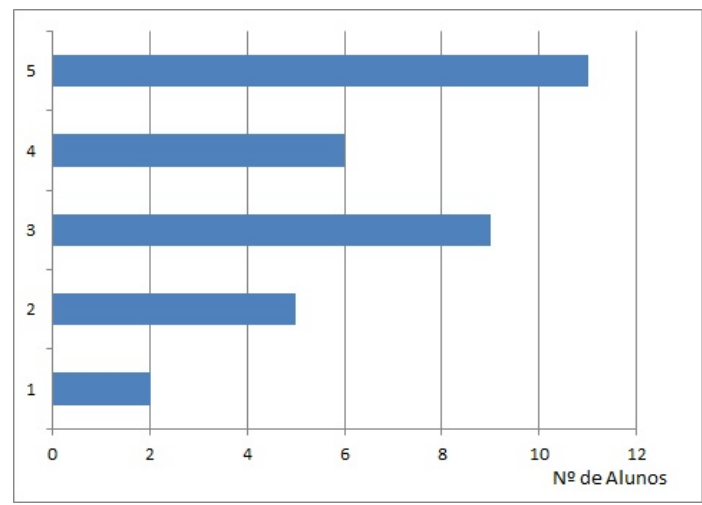

(a) Item A

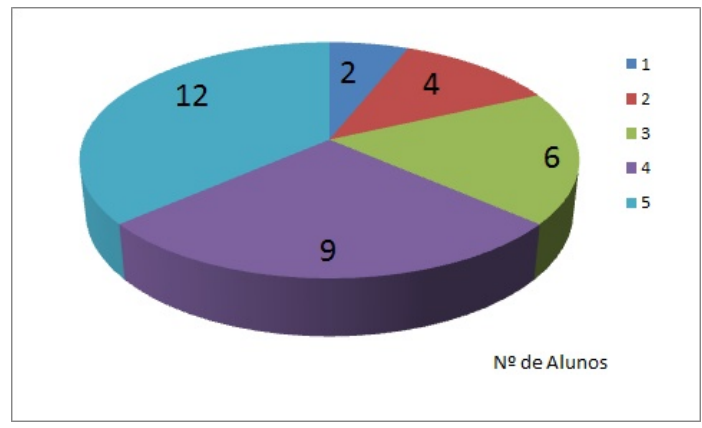

(c) Item C

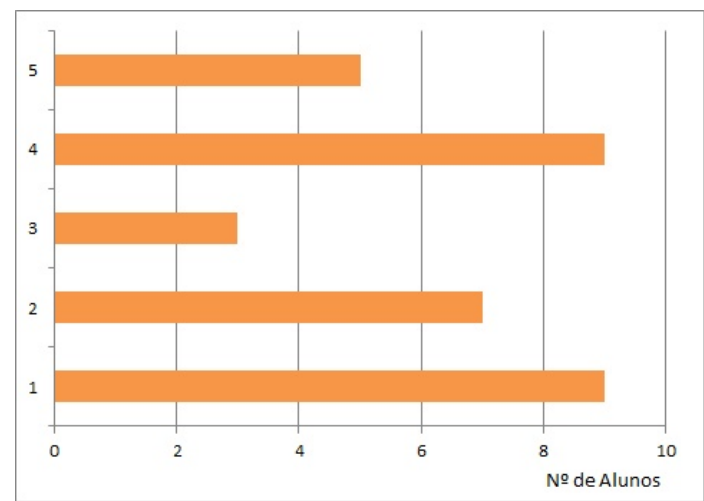

(b) Item B

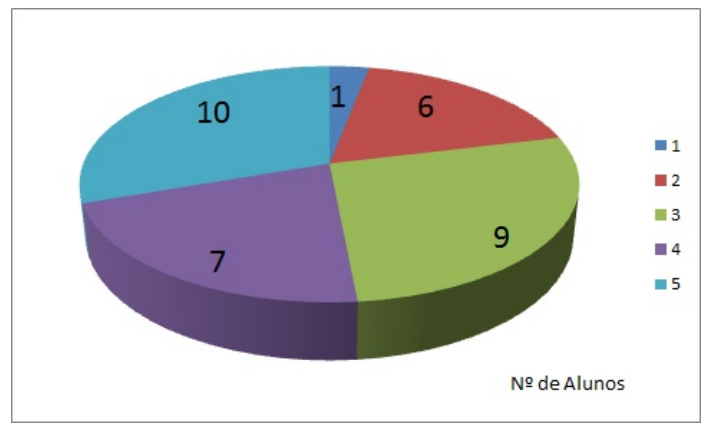

(d) Item D

Figura 4.12: Perguntas sobre o recurso audiovisual

Análise desses gráficos revelam as seguintes observações:

- a situação abordada foi compreendida mais que suficientemente pela maioria da turma;

- houve participação no debate de um número considerável da turma; 
- foi percebido pela turma a relação entre o recurso e o assunto do objeto de conhecimento; e

- a maioria considerável dos alunos reconheceu que o recurso facilitou a aprendizagem.

3 Autoavaliação

A) Estuda e faz as atividades (trabalho, leituras, etc.) exigidas na disciplina?

B) Realiza esforço para compreender e participa ativamente da construção da aula?

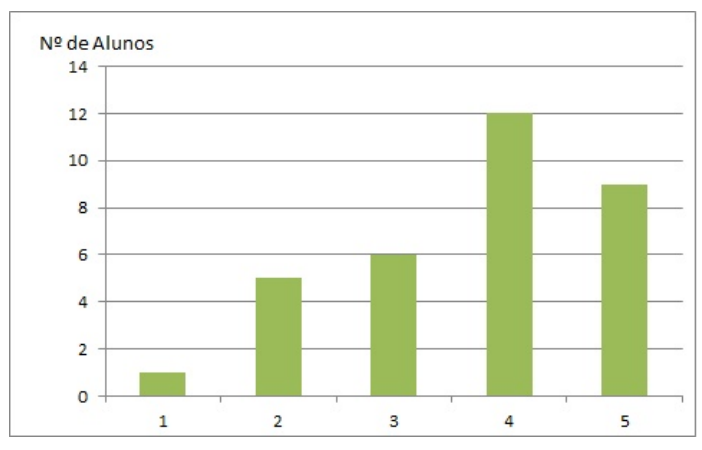

(a) Item A

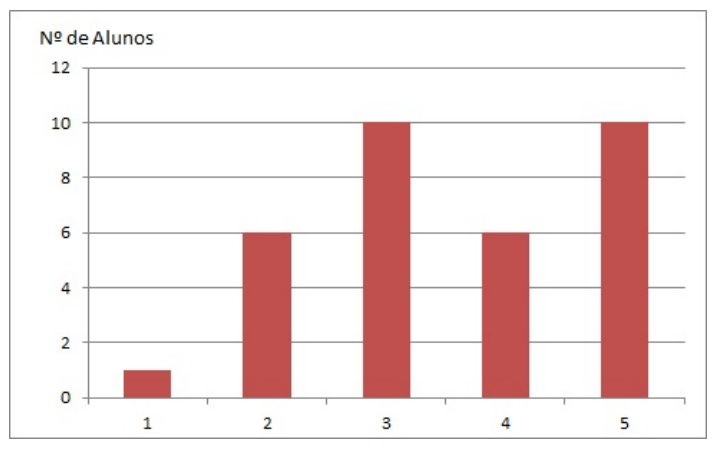

(b) Item B

Figura 4.13: Resultado da autoavaliação

Análise desses gráficos revelam as seguintes observações:

- a maioria dos alunos realizam o estudo necessário para o acompanhamento exigido pela disciplina; e

- o esforço e a dedicação na construção da aula é uma característica comum dos estudantes. 
Capítulo 5

\section{Conclusão}

Neste trabalho optamos por elaborar sequências didáticas próximas UEPS. Tal escolha foi motivada pela proximidade dessa metodologia com o conceito de Aprendizagem Significativa de Ausubel e o socio-interacionismo de Vygotsky. Desta forma, adequar a metodologia de trabalho da pesquisa ao Sistema de Ensino Colégio Militar do Brasil foi possível e proveitoso dada a ênfase do processo de ensino-aprendizagem desse sistema ser pautado no desenvolvimento de habilidades e competências dos discentes. Entretanto, o tamanho do corpo discente da Unidade Colégio Militar de Brasília infringiu um limite para aplicação do produto educacional apenas nas turmas do autor. Além disso, não se pode estender o produto por todo trimestre letivo em virtude de causar uma discrepância consideravél da metodologia adotada em relação a utilizada pelos demais professores do mesmo ano escolar, isto poderia causar um desconforto aos discentes e seus responsáveis.

O movimento harmônico simples e a ondulatória são usualmente os objetos de conhecimento que apresentam um índice acentuado de dificuldade de compreensão por parte dos estudantes do segundo ano do ensino médio. A estrutura matemática requerida para a descrição dos fenômenos que motivam esses assuntos é robusta e usualmente o discente não dispõe dessa linguagem para realizar a mediação entre os fenômenos e sua formulação. Assim, o desinteresse e pouca motivação para sua compreensão se torna comum e fomenta o baixo aproveitamento escolar. Desta forma, modificar a metodologia e utilizar sequências didáticas próximas UEPS pôde proporcionar uma alternativa eficaz para a compreensão do objeto do conhecimento e desenvolvimento de habilidades e competências que proporcionam o letramento ci-

entífico adequado para integrar, e possivelmente superar, o conhecimento do senso 
comum pelo científico.

O produto educacional elaborado por essa pesquisa utiliza três elementos de base para constituição da sequência didática proposta. O primeiro trata-se de vídeos selecionados na internet que abordam situações onde os fenômenos em estudo se manifestam de maneira evidente e assim servirão de organizadores prévios eficientes para o desenvolvimento da sequência didática por meio da utilização de subsunçores que facilitem a aprendizagem. O segundo elemento trabalha com softwares educativos livres e/ou comercializáveis fornecendo subsídios para assimilação e diferenciação progressiva dos fenômenos e objetos do conhecimento abordados. O último elemento realiza uma reconciliação integrativa por meio da utilização de laboratórios didáticos convencionais ou virtuais. Por meio desses elementos foram construídas três sequências didáticas as quais aplicaram-se a (i) descrição do fenômeno oscilatório por meio das relações com o movimento circular, (ii) o fenômeno da inteferência como superposição de ondas de qualquer tipo e por fim (iii) a persepção da frequência da onda em diferentes contextos com destaque para o efeito Doppler.

Uma condição fundamental para aprendizagem significativa está relacionada a pré-disposição do docente em aprender. A fim de verificar esse fator foi aplicado um questionário cuja ênfase foi perceber se a prática docente utilizando recursos variados conseguiu provocar nos estudantes uma expectativa diferenciada de uma aula expositiva convencional. As respostas a tal questionário evidenciaram de forma qualitativa o efeito positivo na aplicação do produto educacional.

Todavia percebe-se que alguns pontos podem ser melhorados nas sequências didáticas introduzindo perspectivas para trabalhos futuros para esse produto educacional:

- produção de vídeos próprios;

- disponibilização do Moodle para acompanhamento do uso dos softwares em tarefas de casa;

- programação do Modellus X para explorar recursos adicionais; e

- utilização de avaliação somativa e formativa para averiguar aprendizagem significativa de forma efetiva. 


\section{Questões apresentadas as turmas nas sequências didáticas a fim de diagnóstico}

A utilização de perguntas para indagar os alunos é um procedimento necessário para reconhecer os conhecimentos prévios dos estudantes. Desta forma foi elaborado um roteiro de questões de múltiplas escolhas utilizadas durante as aulas e cujos resultados eram expressos pela sinalização dos alunos.

\section{A.1 Questões sobre a máquina a vapor e o Movimento Harmô- nico Simples:}

1. Qual(is) o(s) tipo(s) de movimento(s) observado(s) na máquina a vapor?
(A) Movimento Retilíneo.
(B) Movimento Circular.
(C) Movimento Circular Uniforme.
(D) Movimento Harmônico Simples.
(E) Não sei informar.

2. Existe alguma relação entre os movimentos das partes da máquina a vapor?
(A) Não.
(B) Sim.
(C) Não sei informar. 
3. A descrição desse(s) movimento(s) pode ser realizada por qual(is) função(ões) matemática(s)?
(A) Função do $1^{o}$ grau.
(B) Função do $2^{o}$ grau.
(C) Funções trigonométricas.
(D) Não sei informar.

\section{A.2 Questões sobre a propagação das ondas na superfície do lago e interferência:}

1. Qual(is) o(s) tipo(s) de onda(s) observado(s) na superfície do lago?
(A) Longitudinais em uma dimensão.
(B) Transversais em uma dimensão.
(C) Longitudinais em duas dimensões.
(D) Transversais em duas dimensão.
(E) Não sei informar.

2. Qual(is) o(s) elemento(s) da onda que pode(m) ser nitidamente observado(s)?
(A) Comprimento.
(B) Amplitude.
(C) Frequência.
(D) Não sei informar.

3. Qual(is) o(s) fenômeno(s) observado(s) quando é introduzida a segunda fonte?
(A) Batimento.
(B) Ondas Estacionárias.
(C) Interferência.
(D) Não sei informar.

\section{A.3 Questões sobre caracterísicas da frequência e Efeito Dop- pler:}

1. Sobre frequência podemos compreender que são?
(A) Pertubações espaciais da onda.
(B) Pertubações temporais da onda. 
(C) Agudas quando o som é fino.

(D) Graves quando o som é fino.

(E) Algo que não sei informar.

2. Ainda sobre frequência podemos dizer que depende:
(A) da fonte de emissão da onda.
(B) do meio que a onda se propaga.
(C) da fonte de emissão da onda e do meio pelo qual se propaga.
(D) de algo que não sei informar.

3. Caso a fonte de ondas esteja em movimento isso afeta a frequência percebida por meio
(A) da velocidade da onda.
(B) do comprimento da onda.
(C) da própria frequência emitida.
(D) de algo que não sei informar. 


\section{Roteiro de Laboratório Didático}

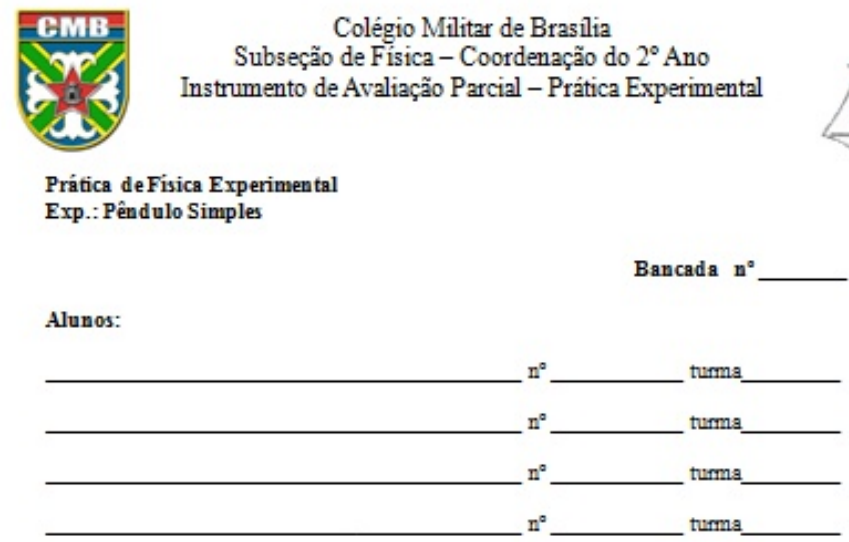

Prática Experimental

A. MATERIAIS UTILIZADOS - Para a realização deste experimento, serão utilizados os seguintes materiais:

1. Discos de Metais;

2. Uma haste com um fios de comprimento a ser determinado, ligando a haste até os discos;

3. Um transferidor, para realizar a medida do ângulo durante o tempo de oacilaçâo do pêndulo;

4. Uma trena para medida do comprimento do barbante;

5. Um cronómetro, para medidas do tempo de oacilaçẩo do pêndulo.

B. PROCEDIMENTO EXPERIMENTAL - Mediçōes

1. (1* Parte) (3 escores) Meça o comprimento Lido fio (Lembre-se de que o comprimento do pêndulo deve ser medido desde o início do fio até o centro do disco).

$\mathrm{R} .: \mathrm{L}_{\mathrm{l}}=$

2. Posicione o pêndulo para um ângulo $\theta$ (valor menor que $15^{\circ}$ ) e solteo. Meça o tempo, t, que 0 pêndulo leva para oscilar 5 vezes e determine o período. Faça isso três vezes.

\begin{tabular}{|l|l|l|l|}
\hline & $1^{x}$ Vez & $2^{x}$ Vez & $3^{x}$ Vez \\
\hline Madida & & & \\
\hline
\end{tabular}

Obtenha uma média simples para o valor medido: $\bar{T}=$ 
3. ( $2^{2}$ Parte) ( 3 escores) Repita o procedimento para $L_{2}$. Faça três vezes cada medida e anote ma Tabela.

$\mathrm{L}_{2}=$

\begin{tabular}{|c|c|c|c|}
\hline & $1^{2} \mathrm{Vez}$ & $2^{2} \mathrm{Vez}$ & $3^{2} \mathrm{Vez}$ \\
\hline Medida & & & \\
\hline
\end{tabular}

Obtenha uma média simples para ovalor medido: $\bar{T}=$

4. ( $3^{a}$ Parte) (3 escores) Modifique a massa do pêndulo $L_{2}$ e realize novamente a mesmo procedimento. Faça três vezes cada medida e anote na Tabela.

\begin{tabular}{|c|c|c|c|}
\hline & $1^{\mathrm{a}} \mathrm{Vez}$ & $2^{\mathrm{a}} \mathrm{Vez}$ & $3^{\mathrm{a}} \mathrm{Vez}$ \\
\hline Medida & & & \\
\hline
\end{tabular}

Obtenha uma média simples para o valor medido: $\bar{T}=$

5. (6 escores) Determine o módulo do campo gravitacional $|\vec{g}|$ em cada uma das três partes da prática.

6. (3 escores) Houve mudanças nos valores obtidos? Por quê? 


\section{Questionário de avaliação das sequências didáticas}

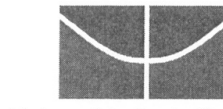

Universidade de Brasília

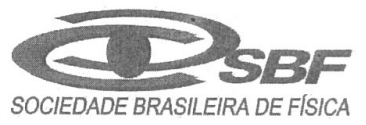

Universidade de Brasília

Mestrado Nacional Profissional em Ensino de Física

Tema: Utilização de Recursos Visuais na aplicação de Metodologia Ativa para ensinoaprendizagem de Física

Orientador: Fabio Ferreira Monteiro

Orientado: Jorge Luís de Araújo Coelho

Questionário de Opinião do Aluno

O objetivo deste questionário é coletar as opiniões dos alunos sobre diferentes aspectos desta disciplina, bem como saber como ele se autoavalia. Os dados fornecerão ao professor condições de refletir sobre sua produtividade com relação ao processo de ensino-aprendizagem. Portanto, a seriedade nas respostas às questões é de suma importância. Para responder às questões, utilize a seguinte escala de valores: 1 - Não; 2 - Sim, pouco(a); 3 - Sim, suficiente; 4 - Sim, satisfatoriamente; 5 - Sim, plenamente.
A) Objeto do Conhecimento - Sequência Didática
1. Conhecia o objeto de conhecimento exposto?
2. A sequência didática foi apresentada pelo professor?
3. A organização dada facilitou a compreensão?
4. Percebeu a importância da disciplina para sua formação ?
B). Recurso Audiovisual
1. Conseguiu compreender a(s) situação(ões) abordadas?
2. Participou ativamente no debate sobre fenômeno observado no recurso audiovisual?
3. Percebeu a relação da situação exposta com o objeto do conhecimento?
4. O recurso audiovisual facilitou o esforço de aprendizagem?
C) Autoavaliação
1. Estuda e faz as atividades (trabalho, leituras, etc.) exigidas na disciplina?
2. Realiza esforço para compreender e participa ativamente da construção da aula? 


\section{Referências Bibliográficas}

[1] NARDI, R.; BASTOS, F.; DINIZ, R. E. S. (Orgs.). Pesquisas em ensino de ciências: contribuições para a formaçãao de professores. São Paulo: Escrituras, 2004.

[2] PACHECO, D. Tarefa de Escola. Campinas: Papirus, 1983.

[3] SOUZA, T. C. F de.; e HEINECK, R. Experiências em Ensino de Ciências, V1(2), pp. 01-09, 2006.

[4] HALlOUN, I. A.; e HESTENES, D. The initial knowledge state of college physics students; Am. J. Phys. 53(11): 1043-1048, 1985.

[5] SASSERON, L. H. Alfabetização Científica e documentos oficiais brasileiros: um diálogo na estruturação do Ensino da Física. Disponível em: $<$ http://moodle.stoa.usp.br/file.php/1129/AC_e_documentos_oficiais_brasilei ros.pdf $>$. Acesso em: 26 Set. 2015.

[6] BRASIL. Ministério de Educação e Cultura. LDB - Lei n ${ }^{o}$ 9394/96, de 20 de dezembro de 1996. Estabelece as diretrizes e bases da Educação Nacional. Brasília : MEC, 1996.

[7] BRASIL. Ministério de Educação. Secretaria de Educação Média e Tecnológica. Parâmetros Curriculares Nacionais (Ensino Médio). Brasília: MEC, 2000.

[8] ARAUJO, I., e MAZUR, E. Instrução pelos colegas e ensino sob medida: uma proposta para o engajamento dos alunos no processo de ensino-aprendizagem de Física. Caderno Brasileiro de Ensino de Física, 30(2), 362-384, 2013. 
[9] MOREIRA, M. A. Unidades de Enseñanza Potencialmente Significativas UEPS. Aprendizagem Significativa em Revista / Meaningful Learning Review, $1(2), 43-63,2011$.

[10] FORMAN, E. The role of peer interaction in the social construction of mathematical knowledge. International Journal of Educational Research Volume 13, Issue 1, Pages 55-70, 1989.

[11] OLIVEIRA, Marta Kohl de. Vygotsky e o processo de formação de conceitos. In: LA TAILlE, Yves de; OLIVEIRA, Marta Kohl; DANTAS, Heloysa (Org.). Piaget, Vygotsky, Wallon: teorias psicogenéticas em discussão. São Paulo, Summus, 1992. p. 24.

[12] MOREIRA, M. A. Teorias de Aprendizagem. São Paulo: EPU, 2014.

[13] PIRES, J. Pequenas Revoluções - Grandes Mudanças. Currículos flexíveis - desafio ou teimosia? Disponível em: <http://historico.ensino.eu/emartigo04.pdf $>$ Acesso em 05 Out. 2015.

[14] BLOOM, B. S.; ENGELHART, M.D.; FURST, E.J. Taxionomia de objetivos educacionais; domínio cognitivo. Porto Alegre, Globo, 1983.

[15] AUSUBEL, D. P., NOVAK, J. D.; HANESIAN, H. Psicologia educacional. Tradução: Eva Nick. Rio de Janeiro: Editora Interamericana Ltda, 1980.

[16] FeitosA, A. M. G; CARDOSO, G. Caderno de Didática - Sistema Colégio Militar do Brasil. Disponível em: <http://www.depa.ensino.eb.br/images/secs/ensino/caderno_de_ditatico.pdf $>$ Acesso em 06 Mai. 2016.

[17] DELORS, J. Educação: Um Tesouro a Descobrir. UNESCO/ MEC: São Paulo: Cortez, 1999.

[18] GENTILE, P; BENCINI, R. Construindo competências: Entrevista com Philippe Perrenoud, Universidade de Genebra. Disponível em: <http://www.unige.ch/fapse/SSE/teachers/perrenoud/php_main/php_2000/2000 1 1.html>. Acesso em: 26 Jan. 2016.

[19] ROSA, C. W.; ROSA, A. B. Ensino de Física: objetivos e imposições no ensino médio. Revista Electrónica de Enseñanza de las Ciencias, Vol. 4 N ${ }^{o}$ 1, 2005. 
"Tudo vale a pena quando a alma não é pequena." 